\title{
Lipoxygenase-induced autoxidative degradation of terrestrial particulate organic matter in estuaries: A widespread process enhanced at high and low latitude
}

Marie-Aimée Galeron ${ }^{\mathrm{a}}$, Olivier Radakovitch ${ }^{\mathrm{b}}$, Bruno Charrière ${ }^{\mathrm{c}}$, Frédéric Vaultier ${ }^{\mathrm{a}}$, John K.

Volkman ${ }^{\text {d }}$, Thomas S. Bianchi ${ }^{\text {e }}$, Nicolas D. Ward ${ }^{\text {f }}$, Patricia M. Medeiros ${ }^{\mathrm{g}}$, Henrique O. Sawakuchi

h, Suzanne Tank ${ }^{\mathrm{i}}$, Philippe Kerhervé ${ }^{\mathrm{c}}$, Jean-François Rontani ${ }^{\mathrm{a}^{*}}$

a Aix Marseille Univ, Université de Toulon, CNRS, IRD, MIO UM 110, Marseille, France, 13288, Marseille, France

b Aix Marseille Univ, CNRS, IRD, Coll France, CEREGE BP80, 13545 Aix-en-Provence, France

Presently at: Institut de Radioprotection et de Sûreté Nucléaire (IRSN). PSE-ENV/SRTE/LRTA. BP3, 13115

Saint-Paul-Les-Durance, France

' Centre de Formation et de Recherche sur les Environnements Méditerranéens (CEFREM, UMR CNRS UPVD 5110), 52 Avenue Paul Alduy, 66860 Perpignan Cedex, France

${ }^{\mathrm{d}}$ CSIRO Oceans and Atmosphere Flagship, GPO Box 1538, Hobart, Tasmania 7001, Australia

${ }^{\mathrm{e}}$ Department of Geological Sciences, Box 112120, University of Florida, Gainesville FL 32611-2120, USA

${ }_{\mathrm{f}}^{\mathrm{f}}$ Marine Sciences Laboratory, Pacific Northwest National Laboratory, 1529 West Sequim Bay Road, Sequim, WA 98382, USA

${ }^{\mathrm{g}}$ Department of Marine Sciences, University of Georgia, Athens, GA 30602-3636, USA

${ }^{\mathrm{h}}$ Center of Nuclear Energy in Agriculture, University of São Paulo, Av. Centenário 303, Piracicaba, SP 13400-970, Brazil

${ }^{i}$ Department of Biological Sciences, University of Alberta, Edmonton, AB, T6G 2E9, Canada

${ }^{*}$ Corresponding author. Tel.: +33-4-86-09-06-02; fax: +33-4-91-82-96-41.

E-mail address: jean-francois.rontani@mio.osupytheas.fr (J.-F. Rontani) 


\section{ABSTRACT}

There exists a substantial amount of research on abiotic (e.g. photochemical) degradation pertaining to organic matter $(\mathrm{OM})$ in the marine realm. While recent research has shown its importance in the degradation of terrestrial particulate OM (TPOM), the mechanisms involved in the induction of autoxidation in estuaries remain unclear. In this study, we propose for the first time the involvement of lipoxygenase (LOX) activity in the induction of autoxidation in mixed waters. The observation of unusual profiles of palmitoleic acid oxidation products and the presence of jasmonic acid in suspended particulate matter (SPM) collected close to the Rhône River, as well as in samples from the Mackenzie and Amazon rivers, is attributed to strong LOX activity. We show the role played by salinity in the induction of this LOX activity and provide an explanation for the differences in estuarine autoxidation level. At high latitude, lower temperatures and irradiance favor photooxidative damage to higher plant debris and, consequently, hydroperoxide production. High hydroperoxide content strongly contributes to LOX activation in mixed waters. The high resulting LOX activity enhances alkoxyl radical production and thus autoxidation. On the contrary, at low latitude, photooxidative effects are limited, and riverine autoxidation is favored. The higher hydroperoxide content of TPOM may, as a consequence, thereby also contribute to a high level of LOX activity and autoxidation in estuaries. In temperate zones, land and riverine photooxidative and autoxidative damage is limited, unlike estuaries where we observed significant LOX-induced and autoxidative damage.

Keywords: Terrestrial organic matter; Estuaries; Degradation; Autoxidation; Lipoxygenase; Arctic, Temperate and tropical zones. 


\section{Introduction}

Riverine particulate organic matter (POM), which consists in part of highly degraded residues from terrestrial higher plants, has long considered to be refractory compared with marine-derived POM (de Leeuw and Largeau, 1993; Wakeham and Canuel, 2006). The assumption is not supported by the unexpected relatively low proportion of land-derived OM detected in marine sediments (Hedges and Keil, 1995), suggesting extensive remineralization of this material at sea (Hedges et al., 1997). In fact, the notion of OM being inherently refractory and/or labile in terrestrial and aquatic systems has been recently challenged, with the suggestion that the all this material is utilized by microbes under the "right" environmental conditions (Bianchi, 2011; Schmidt et al., 2011). Moreover, several studies have demonstrated that POM delivered by rivers is sensitive to microbial remineralization in some shelf areas (Aller et al., 1996; Aller, 1998; Mayer et al., 2008; van Dongen et al., 2008; Sampere et al., 2008; Vonk et al., 2010; Bourgeois et al., 2011; Karlsson et al., 2011). More recently, it has been shown that processes such as biodegradation and autoxidation (free radical reaction of organic compounds with $\mathrm{O}_{2}$ ) play a key role in the degradation of vascular plant-derived lipids discharged by the Mackenzie River to the Beaufort Sea (Rontani et al., 2014a).

Autoxidation is not spontaneous but autocatalytic; once started, it is self-propagating and self-accelerating (Schaich, 2005). The mechanisms of initiation have been debated for many years, but likely involve the homolytic cleavage of photochemically produced hydroperoxides in phytodetritus (Girotti, 1998; Rontani et al., 2003). The cleavage may be induced by heat, light, metal ions and lipoxygenases (Schaich, 2005). Autoxidation, largely ignored for the coastal zone, proceeds by a radical chain reaction and acts mainly on organic compounds possessing $\mathrm{C}=\mathrm{C}$ bonds or $\mathrm{C}-\mathrm{H}$ bonds whose bond energy is relatively low (e.g. allylic, tertiary, $\alpha$ to oxygen, etc.; Fossey et al., 1995). It can act not only on unsaturated lipids [e.g. sterols, unsaturated fatty acids (FAs), chlorophyll phytyl side chain, alkenes, tocopherols and alkenones; Rontani, 2012], but also on amino acids (Seko et al., 2010), sugars (Lawrence et al., 2008) and polyphenols (Hathway and Seakins, 
1957). It can also affect biopolymers (Schmid et al., 2007) and kerogen, inducing ring opening and chain cleavage.

To explain this induction, a mechanism involving homolytic cleavage of photochemically produced hydroperoxides, resulting from the senescence of higher plants on land, was proposed (Galeron et al., 2016c). Cleavage was attributed to some redox-active metal ions released from suspended particulate matter (SPM) in the mixing zone of riverine water and marine water. Using new lipid tracers specific to the degradation of terrestrial higher plants at the mouth of the Rhône River (Galeron et al., 2016a,b; Rontani et al., 2015), we confirmed the role played by autoxidation in the degradation of terrestrial POM (TPOM) in estuaries (Galeron et al., 2017). As in the Beaufort Sea (Rontani et al., 2014a), autoxidation rate and salinity level appeared to correlate well within the river plume in the Mediterranean Sea (Galeron et al., 2017). However, it was not possible to detect a significant release of metal ions (able to catalyze hydroperoxide cleavage) during that study. Four important questions thus remained to be elucidated: (i) Which processes promote induction of autoxidation of TPOM in estuarine waters, (ii) why is autoxidation induced in TPOM in mixed waters (i.e. during an increase in salinity), (iii) why is autoxidation of TPOM enhanced in Arctic vs. temperate estuaries and (iv) what is the role of autoxidation in tropical zones? In order to answer these questions, the degradation of TPOM in several SPM and surface sediment samples collected from three contrasting key areas was monitored: (1) Arctic Ocean (Mackenzie River and Shelf), (2) tropical Atlantic Ocean (Amazon River and Shelf) and (3) Mediterranean Sea (Rhône River and Shelf).

The Arctic Ocean receives the largest riverine input of all the oceans, relative to its size. More specifically, its upper layer, which represents only $0.1 \%$ of the global ocean volume, receives $11 \%$ of the global riverine discharge (Fichot et al., 2013). Moreover, since global warming has accelerated twice as rapidly in the northern Hemisphere (Kug et al., 2015) than other regions of the globe, the Arctic remains a key focal point for climate change research. With a huge watershed (1.8 
$\times 10^{6} \mathrm{~km}^{2}$ ) and annual water discharge of $330 \mathrm{~km}^{3} / \mathrm{yr}$ delivered mainly in the short summer period, the Mackenzie is the fourth largest Arctic river and the primary source of particulate matter (PM) in the Arctic Ocean (e.g. Hilton et al., 2015). Its total suspended matter load was estimated at 40-160 $\mathrm{Mt} / \mathrm{yr}$ and its particulate organic carbon (POC) flux at 0.2-2.2 Mt/yr (Macdonald et al., 1998; Doxaran et al., 2015).

The Mediterranean is a semi-enclosed sea subject to both anthropogenic pressure and climate change. Since the damming of the Nile, it is the main supplier of fresh water $\left(55 \mathrm{~km}^{3} / \mathrm{yr}\right)$, suspended matter (2-8 Mt/yr) and POC (0.2 Mt/yr) to the Mediterranean (Sempéré et al., 2000; Sadaoui et al., 2016). The Rhône River is 816 km long with a drainage area of $97,800 \mathrm{~km}^{2}$.

The Amazon is the largest river in the world, with a drainage basin area of $6.1 \times 10^{6} \mathrm{~km}^{2}$ (Goulding et al., 2003) covered by diverse vegetation, including tropical rainforest, inundated floodplain ('várzea') forest, floating grass and extensive grassland/savannah (Hedges et al., 1986). Its discharge has a strong seasonal variation, with a maximum of 7,500 $\mathrm{km}^{3} / \mathrm{yr}$ in May-June and a minimum of 2,500 $\mathrm{km}^{3} / \mathrm{yr}$ in October-November (Lentz, 1995). The total export of POC from the historic gauging station, Óbidos, to the ocean was estimated at 12.8-14.4 Mt/yr (Moreira-Turcq et al., 2013). However the POC load has been reported to decrease by ca $50 \%$ between Óbidos and the river mouth, $850 \mathrm{~km}$ further downstream (Ward et al., 2015).

Here we evaluate the mechanisms that induce autoxidation across a diverse suite of high to low latitude river-to-ocean gradients. Since it is well known that peroxidation of membrane lipids by lipoxygenases (LOXs) may play an important role in promoting oxidative damage during environmental stress (Thompson et al., 1987), we hypothesize that LOX activity is directly related to level of estuarine TPOM autoxidation and that the balance between photo-, bio-, and auto-oxidative TPOM breakdown depends on salinity, temperature, and light penetration.

\section{Methods}




\subsection{Sampling of SPM and sediments from the Rhône, Mackenzie and Amazon rivers and shelfs}

SPM samples were collected in February 2012 along a transect following the salinity gradient in the Rhône plume (Fig. 1). Sampling and hydrographic conditions have been described by Galeron et al. (2017). High frequency monitoring of the nutrients and of the PM input from the Rhône to the Mediterranean has been carried out since 2010 in the framework of the national program MOOSE (Mediterranean Ocean Observing System for the Environment). Monitoring is undertaken at the Arles station $\left(43^{\circ} 40^{\prime} 44^{\prime \prime} \mathrm{N}, 4^{\circ} 37^{\prime} 16^{\prime \prime} \mathrm{E}\right), 40 \mathrm{~km}$ upstream from the river mouth (Fig. 1). In-river sampling included particle collection using a Teflon-coated high speed centrifuge (CEPA Z61). Sediment material $(0-1 \mathrm{~cm})$ was collected in August 2006 at stations R28 and R30 in the Rhône prodelta (Fig. 1) using a box multitube corer. Sediments were immediately frozen at $-20{ }^{\circ} \mathrm{C}$ on board, then freeze-dried and stored in the dark in the laboratory until analysis.

SPM samples from the Mackenzie River were collected in Tsiigehtchic $\left(67^{\circ} 27^{\prime} 7^{\prime \prime} \mathrm{N}\right.$, $133^{\circ} 45^{\prime} 32^{\prime \prime} \mathrm{W}$ ) in June 2011 (Fig. 1), using the same protocol as that used for the Rhône plume SPM collection (Galeron et al., 2017). Sediment material was collected at station M434 near to the river mouth $\left(70^{\circ} 10^{\prime} 12^{\prime \prime} \mathrm{N}, 133^{\circ} 35^{\prime} 24^{\prime \prime} \mathrm{W}\right)$ as part of the ArcticNet and IPY-CFL system studies on board the CCGS Amundsen in 2008. A surface sample (ca. 0-1 cm) was collected from a box core, freeze dried and stored $\left(<4{ }^{\circ} \mathrm{C}\right)$ prior to analysis.

Particles from the Amazon were collected in the Solimões River (near the city of Manacapuru, $03^{\circ} 19^{\prime} 29^{\prime \prime} \mathrm{N}, 60^{\circ} 32^{\prime} 58^{\prime \prime} \mathrm{W}$ ) in June 2005 and March 2006, and in the Madeira River (near its mouth where it reaches the Amazon; 032 $27^{\prime} 24^{\prime \prime} \mathrm{N}, 58^{\circ} 47^{\prime} 57^{\prime \prime} \mathrm{W}$ ) in June 2005 (Fig. 1). Surface sediments were collected along the tidally influenced reaches of the lower Amazon near the city of Almeirim $\left(1^{\circ} 34^{\prime} 428^{\prime \prime} \mathrm{S}, 52^{\circ} 40^{\prime} 79^{\prime \prime} \mathrm{W}\right)$ and in the two main north/south channels at the river mouth near the city of Macapá $\left(00^{\circ} 05^{\prime} 240^{\prime \prime} \mathrm{S}, 50^{\circ} 37^{\prime} 212^{\prime \prime} \mathrm{W}\right.$ and $00^{\circ} 09^{\prime} 249^{\prime \prime} \mathrm{S}, 51^{\circ} 03^{\prime} 120^{\prime \prime} \mathrm{W}$, respectively). Sediment samples from the lower Amazon were collected near the river margin using a 
Van Veen grab. Samples were stored in $50 \mathrm{ml}$ sterilized centrifuge tubes and frozen at $-20{ }^{\circ} \mathrm{C}$ prior to analysis.

In the tropical Atlantic, particle samples were collected in 2011 and 2012 at the surface (ca. 2 m) using a gentle impeller pumping (modified Rule 1800 submersible pump) through $10 \mathrm{~m}$ of Tygon tubing to the ship's deck. Immediately after collection, 2-5 1 of plume water were filtered through $0.7 \mu \mathrm{m}$ Whatman $\mathrm{GF} / \mathrm{F}$ filters (pre-combusted at $450{ }^{\circ} \mathrm{C}$ for $5 \mathrm{~h}$ ), carefully wrapped using precombusted $\mathrm{Al}$ foil, and kept frozen at $-20{ }^{\circ} \mathrm{C}$ until analysis. Sediments were collected using a multicorer with $9.8 \mathrm{~cm}$ (i.d.) core tubes from depths of 4000-4600 m (Table 3). Immediately after recovery, cores were transferred to a temperature-controlled cold van (ca. $2^{\circ} \mathrm{C}$ ), where sediments were sectioned in $1 \mathrm{~cm}$ intervals, and the top layer was transferred to pre-combusted $\mathrm{Al}$ foil, carefully wrapped and kept frozen at $-20{ }^{\circ} \mathrm{C}$ until analysis.

\subsection{Incubation of SPM at different salinity values}

In order to determine the degradation kinetics of the Rhône SPM upon reaching seawater, we incubated SPM from the river at different salinity values. Rhône water was collected on November 18, 2014, during a flood (water flow $3700 \mathrm{~m}^{3} / \mathrm{s}$, SPM $217.1 \mathrm{mg} / \mathrm{l}$, POC $119.01 \mu \mathrm{M}$ ) and seawater (salinity $38 \mathrm{~g} / \mathrm{kg}$ ) during the MORTIMER sampling campaign of November 12, 2014 (Galeron et al., 2017). Dilution was carried out with 11 glass flasks using Rhône water and filtered $0.7 \mu \mathrm{m}$ seawater in order to reach salinity of 0 (Rhône water only), 15 and $25 \mathrm{~g} / \mathrm{kg}$. No extra SPM was added to the dilutions since the collected Rhône water displayed a sufficiently high level of SPM for incubation. Flasks were kept at room temperature in the dark, and mixed and oxygenated every other day. Filtering for analysis occurred after 102 days, for each salinity level. For each incubation flask, $3 \times$ $250 \mathrm{ml}$ incubated water (triplicate) were filtered on pre-combusted GF/F filters (Whatman). Filters were immediately frozen at $-20{ }^{\circ} \mathrm{C}$ until analysis. 


\subsection{Treatment of SPM and sediment samples}

After thawing, filters were reduced with $\mathrm{NaBH}_{4}$ and saponified. $\mathrm{NaBH}_{4}$ reduction of hydroperoxides to alcohols is essential for estimating the importance of photooxidative and autoxidative degradation in natural samples (Marchand and Rontani, 2001). Without this treatment, these labile compounds could be thermally cleaved during alkaline hydrolysis or gas chromatography (GC) analysis and thereby be overlooked during conventional organic geochemical studies. All manipulations were carried out using foil-covered vessels in order to exclude photochemical artifacts. It is well known that metal ions can promote autoxidation during hot saponification (Pokorny, 1987). Prior reduction of hydroperoxides with $\mathrm{NaBH}_{4}$ allowed us to avoid such autoxidation artifacts during the alkaline hydrolysis.

Filters were placed in $\mathrm{MeOH}(20 \mathrm{ml})$ and hydroperoxides were reduced to the alcohols with excess $\mathrm{NaBH}_{4}\left(70 \mathrm{mg} ; 30 \mathrm{~min}\right.$ at $\left.20{ }^{\circ} \mathrm{C}\right)$. During this treatment, ketones are also reduced to alcohols and the possibility of some ester cleavage cannot be totally excluded. Saponification was carried out on reduced samples. After $\mathrm{NaBH}_{4}$ reduction, $20 \mathrm{ml}$ water and $2.8 \mathrm{~g} \mathrm{KOH}$ were added and the mixture directly saponified by refluxing for $2 \mathrm{~h}$. After cooling, the flask contents were acidified with $\mathrm{HCl}(\mathrm{pH} 1)$ and extracted (3x) with dichloromethane (DCM). The combined DCM extracts were concentrated to give the total lipid extract (TLE). After solvent evaporation, the residue was taken up in $300 \mu \mathrm{l}$ pyridine/N,O-bis(trimethylsilyl)trifluoroacetamide (BSTFA; Supelco; 2:1, v:v) and silylated for $1 \mathrm{~h}$ at $50{ }^{\circ} \mathrm{C}$ to convert $\mathrm{OH}$-containing compounds to trimethylsilyl ether or ester derivatives. After solvent removal under a stream of $\mathrm{N}_{2}$, the derivatized residue was taken up in 100 $\mu \mathrm{BSTFA}$ (to avoid desilylation of FAs) and an amount of solvent (EtOAc) depending on the mass of the TLE.

\subsection{GC-EI tandem mass spectrometry (GC-EIMS-MS)}


GC-EIMS-MS was performed in multiple reaction monitoring (MRM) mode using an Agilent 7890A/7000A tandem quadrupole gas chromatograph system (Agilent Technologies, Parc Technopolis - ZA Courtaboeuf, Les Ulis, France). Operating conditions are described by Rontani et al. (2016).

\subsection{GC-quadrupole time of flight mass spectrometry (GC-QTOF)}

Accurate mass measurements were carried out in full scan mode with an Agilent 7890B/7200 GC-QTOF System (Agilent Technologies, Parc Technopolis - ZA Courtaboeuf, Les Ulis, France). Operating conditions are described by Rontani et al. (2017).

\subsection{Standards}

Quantification of lipids and their oxidation products was carried out using GC-EIMS-MS or GC-QTOF with the following external standards. FAs, sterols, amyrins, betulin and jasmonic acid were from Sigma-Aldrich. $\mathrm{NaBH}_{4}$ reduction of commercial jasmonic acid (containing a small proportion of iso-jasmonic acid) afforded isomeric cucurbic acids. Oxidation products of monounsaturated FAs, sitosterol, amyrins and betulin were produced according to previously described procedures (Marchand and Rontani, 2001; Rontani et al., 2014a; Galeron et al., 2016a,b). A standard of threo 7,10-dihydroxyoctadec-8(E)-enoic acid containing $10 \%$ of threo 7,10dihydroxyhexadec-8(E)-enoic acid produced by Pseudomonas aeruginosa PR3 (Suh et al., 2011) was obtained from H.R. Kim (School of Food Science and Biotechnology, Kyungpook National University, Daegu, South Korea).

\subsection{Estimation of autoxidative, photooxidative and LOX degradation}

Sitosterol and more specific triterpenes (betulin, $\alpha$ - and $\beta$-amyrins) were used to estimate the oxidation state of higher plant material. The proportions of photooxidation and autoxidation of 
sitosterol were estimated from 24-ethylcholest-4-en-3 $\beta, 6 \alpha / \beta$-diol and 24-ethylcholesta-3 $\beta, 5 \alpha, 6 \beta$ triol concentration, respectively, using equations proposed by Christodoulou et al. (2009) and Rontani et al. (2009). Autoxidation state of $\alpha$ - and $\beta$-amyrins was estimated thanks to the proportion of 11-oxo- $\alpha$-amyrin and 11-oxo- $\beta$-amyrin, respectively (Galeron et al., 2016b). In the case of betulin, estimation of autoxidation was carried out with lupan-20-one-3 $\beta, 28$-diol (Galeron et al., 2016a). The part played by autoxidation in the degradation of palmitoleic acid was estimated thanks to the proportion of its specific Z-oxidation products (Frankel, 1998) and of the water temperature according to the approach described by Marchand and Rontani (2001). After subtraction of the amounts of oxidation products of autoxidative origin, it remained to determine the relative parts played by photooxidative and enzymatic processes in the degradation. Taking into account the production of equal amounts of 9-E and 10-E oxidation products during the photooxidation of the $\Delta^{9}$ monounsaturated FA (Frankel, 1998) and their specific allylic rearrangement to $11-E$ and 8-E isomers, respectively (Porter et al., 1995), the part played by photooxidative degradation was estimated to be $2 \times(9-E+11-E)$. Concerning $10 S$-DOX degradation, this was obtained from the difference between $(10-E+8-E)$ and $(9-E+11-E)$ oxidation products, to which was added the amount of threo 7,10-dihydroxyhexadec-8(E)-enoic acid formed.

\section{8. $\delta^{13}$ C analysis}

Compound specific carbon isotope $\left(\delta^{13} \mathrm{C}\right)$ analysis was performed on the TLE using a HP7890B gas chromatograph coupled to an Isoprime Vision stable isotope ratio mass spectrometer via a GC-5 combustion interface at $870{ }^{\circ} \mathrm{C}$. The GC instrument was equipped with a BPX5 column (30 $\mathrm{m} \times 0.25 \mathrm{~mm} \times 0.10 \mu \mathrm{m}$ film thickness) and a cool on-column injector, with He as carrier gas (1 $\mathrm{ml} / \mathrm{min}$ ). Samples were injected at $60{ }^{\circ} \mathrm{C}$ and the oven temperature was ramped to $130{ }^{\circ} \mathrm{C}$ at 20 ${ }^{\circ} \mathrm{C} / \mathrm{min}$, then to $300{ }^{\circ} \mathrm{C}$ (held $30 \mathrm{~min}$ ) at $4{ }^{\circ} \mathrm{C} / \mathrm{min}$. Samples were analyzed in duplicate and the $\delta^{13} \mathrm{C}$ 
values were corrected for instrument deviation using the Indiana University B4 mixture and for the BSTFA derivatizing agent (Jones et al., 1991).

\section{Results}

\subsection{Re-examination of SPM samples from Rhône estuary}

In order to identify the processes causing the induction of autoxidation in coastal waters, TLEs from different SPM samples previously collected (Galeron et al., 2017) from the Rhône and along a transect in its estuary (Fig. 1) were re-examined. These samples were subjected to $\mathrm{NaBH}_{4}$ reduction (allowing analysis of labile hydroperoxides in the form of the corresponding alcohols) and subsequent alkaline hydrolysis (allowing hydrolysis of esterified lipids). Unusual profiles of $\mathrm{C}_{16: 1 \omega 7}$ (palmitoleic) acid oxidation products dominated by 10-hydroxyhexadec-8(E)-enoic and 8hydroxyhexadec-9(E)-enoic acid were observed at stations R1 and R7 close to the river mouth (Fig. 2). Indeed, singlet oxygen-mediated photooxidation of $\Delta^{9}$ monounsaturated FAs such as palmitoleic acid produces (after $\mathrm{NaBH}_{4}$ reduction) equal proportions of isomeric 9- and 10-hydroxyacids with an allylic $E$ double bond (Frankel, 1980), which can subsequently undergo highly stereoselective radical allylic rearrangement to $11-E$ and $8-E$ hydroxyacids, respectively (Porter et al., 1995). In contrast, autoxidation (free radical induced oxidation) produces a mixture of 9-E, 10-E, 11-E, 11-Z, 8-E and 8$Z$ hydroxyacids also exhibiting equal proportions of the major 9- $E$ and $10-E$ isomers (Frankel, 1998). The strong predominance of the $10-E$ isomer (and its allylic rearrangement product $8-E$ ) relative to the 9-E isomer (and its allylic rearrangement product 11-E) observed at the stations closer to the river mouth (Fig. 2) is thus particularly interesting. It should be noted that diastereoisomers of 7,10dihydroxyhexadec-8(E)-enoic acid could be also detected at these stations (Fig. 2).

To obtain information about the origin of palmitoleic acid and its oxidation products, the stable carbon isotopic $\left(\delta^{13} \mathrm{C}\right)$ signatures of the main lipids were measured in SPM samples from R1 
and R7 (Table 1). This monounsaturated FA is usually a minor component of higher plants (Bridson, 1985), in these samples it was therefore more likely derived from bacteria and/or phytoplankton. Based on its depleted $\delta^{13} \mathrm{C}$ signatures ( $-30.9 \%$ and $-27.8 \%$ at $\mathrm{R} 1$ and $\mathrm{R} 7$, respectively), we can likely assume that the contribution from marine phytoplankton $\left(\delta^{13} \mathrm{C}\right.$ values generally $-19 \%$ o to 24\%; Tolosa et al., 2013) to this acid was negligible. Moreover, the relatively enriched $\delta^{13} \mathrm{C}$ signature of 24-methylenecholesterol (a well-known diatom marker; Volkman, 2003) at R7 (21.6\%o) (Table 1) attests to the lack of freshwater phytoplankton [which typically exhibits more depleted $\delta^{13} \mathrm{C}$ values (-34\%o to $-36 \%$; Tolosa et al., 2013)] in these samples. Thus, the main source of palmitoleic acid was likely riverine bacteria growing on $\mathrm{C}_{3}$ terrestrial plant material.

The preferred substrates for LOXs in plants are $\mathrm{C}_{18: 2 \omega 6}$ (linoleic) and $\mathrm{C}_{18: 3 \omega 3}(\alpha$-linolenic) FAs (Siedow, 1991). $\alpha$-Linolenic acid is converted to 7-iso-jasmonic and jasmonic acids by a series of enzymatic reactions in the chloroplast (Kazan and Manners, 2008; Fig. 3). To determine if LOX activity increased in higher plant detritus at stations closer to the Rhône mouth, we quantified using GC-MS-MS in MRM mode isomeric cucurbic acids resulting from the reduction of 7-iso-jasmonic and jasmonic acids during the treatment (Fig. 3). The transitions employed were based on specific fragmentations of isomeric cucurbic acid trimethylsilyl ether derivatives recently elucidated by Rontani et al. (2016). Interestingly, the values of the ratio $\Sigma$ cucurbic acids/parent $\alpha$-linolenic acid appeared to be more than two orders of magnitude higher at station R1 than in the Rhône River (Table 2).

\subsection{Incubation of SPM from Rhône River at different salinity values}

Past works indicated that LOX activity increases significantly in higher plants cultivated in a NaCl-supplemented medium (Rodriguez-Rosales et al., 1999; Mittova et al., 2002; Zhang et al., 2012). The effect of this higher LOX activity can be either deleterious (increasing formation of FA hydroperoxides and free radicals inducing membrane deterioration) or beneficial (increasing 
formation of jasmonic acid, which participates in the onset of defense reactions to biotic and abiotic stress) to the cells (Rodriguez-Rosales et al., 1999). To determine if LOXs were activated in higher plant debris carried by rivers during the mixing of riverine and marine waters, SPM from the Rhône was incubated at room temperature under darkness at different salinity values. Concentrations of isomeric cucurbic acids ( $\mathrm{NaBH}_{4}$-reduced 7-iso-jasmonic and jasmonic acids) after incubation for 102 days increased significantly with increasing post incubation salinity $(2.8 \pm 0.4 \mathrm{ng} / \mathrm{g}$ dry wt at $\mathrm{S}=0$ $\mathrm{g} / \mathrm{kg}, 4.3 \pm 0.7 \mathrm{ng} / \mathrm{g}$ dry wt at $\mathrm{S}=15 \mathrm{~g} / \mathrm{kg}$ and $14.5 \pm 5.0 \mathrm{ng} / \mathrm{g}$ dry wt at $\mathrm{S}=25 \mathrm{~g} / \mathrm{kg}$ ) (Table 3 ).

\subsection{Examination of SPM from the Amazon}

In SPM samples from the Solimões and Madeira rivers, in the central Amazon River basin, we observed relatively low sitosterol photooxidation, averaging $11.8 \pm 2.2 \%$, with photooxidation products of phytol, oleic and palmitoleic acids below limits of detection. Autoxidation was, on the other hand, much higher than for the Rhône River (Galeron et al., 2017), with conversion averaging $55.0 \pm 1.6 \%$ for sitosterol, $73.8 \pm 7.0 \%$ for $\alpha$-amyrin and $56.8 \pm 15.5 \%$ for $\beta$-amyrin. A high proportion of sitostanol (ranging from 40 to $78 \%$ of the parent sterol for the different stations) was also detected in these samples.

\subsection{Comparison of efficiency of autoxidative degradation in vascular plant debris of Arctic,} temperate and tropical coastal zones

To compare the efficiency of autoxidation in vascular plant debris discharged by temperate and tropical rivers with that previously measured in Arctic sediments (Rontani et al., 2017), oxidation products of specific tracers of vascular plants ( $\alpha$ - and $\beta$-amyrins and betulin) were quantified in surface sediment $(0-1 \mathrm{~cm})$ and SPM samples from the Amazon River, fan and shelf and surface sediment $(0-1 \mathrm{~cm})$ from the Rhône Shelf. The extent of autoxidation of vascular plant debris appeared to be considerably higher in the Amazon Shelf than in the Rhône Shelf (Table 4). 
Interestingly, diastereoisomeric 7,10-dihydroxyhexadec-8(E)-enoic acids could be detected in sediments from M434 and in SPM from A8 (Fig. 4).

\subsection{Quantification of $11 \alpha$-hydroperoxyamyrins in SPM from Rhône, Mackenzie and Amazon rivers}

It was previously demonstrated that autoxidation of $\alpha$ - and $\beta$-amyrins produces stable $11 \alpha$ hydroperoxides (Galeron et al., 2016b). These compounds, which are not affected by $\mathrm{NaBH}_{4}$ reduction, are thermally cleaved to the corresponding ketones during GC injection (Galeron et al., 2016b). Thus, they were quantified in the form of 11-oxoamyrins in SPM samples from the Rhône, Mackenzie and Amazon rivers and their hydroperoxide nature was confirmed in subsamples after reduction with $\mathrm{LiAlD}_{4}$. The results clearly showed the presence of a higher proportion of 11hydroperoxyamyrins in SPM from the Mackenzie and Amazon rivers than in SPM from the Rhône River (Table 5).

\subsection{Quantification of isomeric cucurbic acids in SPM from Amazon and Mackenzie rivers}

Isomeric cucurbic acids resulting from $\mathrm{NaBH}_{4}$ reduction of 7-iso-jasmonic and jasmonic acids (products of linolenic acid degradation by lipoxygenases; Kazan and Manners, 2008), were also quantified in SPM from the Amazon and Mackenzie rivers (Fig. 5). The results showed: considerably higher values of this ratio in the Amazon and Mackenzie rivers than in the Rhône estuary and shelf (Table 2).

\section{Discussion}

4.1. Rhône River and Mediterranean shelf waters

4.1.1. Origin of induction of autoxidation processes in POM in coastal waters 
$\delta^{13} \mathrm{C}$ analyses revealed that palmitoleic acid at $\mathrm{R} 1$ and $\mathrm{R} 7$ likely derived from riverine bacteria that appeared to grow on $\mathrm{C}_{3}$ terrestrial plant material (Table 1). The similar $\delta^{13} \mathrm{C}$ values of $\mathrm{C}_{18: 1 \omega 7}$ (vaccenic) and branched pentadecanoic acids (FAs specific to bacteria; Sicre et al., 1988) measured by Bourgeois et al. (2011) in sediments from the same deltaic region of the Rhône River provide further evidence for the presence of FAs derived from bacteria utilizing vascular plant sources.

The predominance of $10-E$ and $8-E$ hydroxyacids among the oxidation products of palmitoleic acid was thus attributed to the involvement of a specific bacterial enzymatic process and more precisely a LOX-like activity. LOXs are non-heme iron dioxygenases responsible for a wide range of functions (e.g. regulation of host defense, stress response, inflammation and development) in eukaryotes (Garreta et al., 2016). They are also found in some prokaryotes, where their possible biological role remains unclear. A $10 S$-DOX-like lipoxygenase was notably isolated from Pseudomonas aeruginosa 42A2 (Guerrero et al., 1997; Busquets et al., 2004). Interestingly, the activity of this enzyme is highest in the case of FAs containing a double bond at $\Delta^{9}$. In fact, this $10 S$ DOX-like lipoxygenase converts palmitoleic acid to 10(S)-hydroperoxyhexadec-8(E)-enoic acid, which may then undergo stereoselective allylic rearrangement (Porter et al., 1995) to 8hydroperoxyhexadec-9(E)-enoic acid (Fig. 6). The involvement of such enzymes could thus explain the unusual dominance of isomers $10-E$ and $8-E$ among palmitoleic acid oxidation products at stations closer to the Rhône mouth (Fig. 2). This assumption is supported by the detection of threo 7,10-dihydroxyhexadec-8(E)-enoic acid in these samples (Fig. 2). Indeed, the $10(S)$ hydroperoxyhexadec-8(E)-enoic acid produced by $P$. aeruginosa $42 \mathrm{~A} 2$ is then converted to $7(S), 10(S)$-dihydroxyhexadec-8(E)-enoic acid by way of a diol synthase (Fig. 6; Gardner and Hou, 1999). The presence of erythro isomers (Fig. 2) likely resulted from the involvement of hydroperoxide isomerase, well known to produce these enantiomers (Jernerén et al., 2010). The combined bacterial (10S)-DOX and diol synthase activities, which may be expressed extracellularly 
(Kim et al., 2000), may be associated with the modification of the membrane lipids or could contribute to detoxification of FAs in the bacterial environment, promoting colonization and growth (Martinez et al., 2010).

The relative parts played by autoxidation, photooxidation and LOX activities in the degradation of this acid could be estimated for the Rhône River and along the coastal transect investigated. The results obtained showed a lack of LOX reactions in the Rhône River itself, with a greater contribution of LOX reactions to degradation at stations closer to the river mouth and a dominance of autoxidation at the more distant marine stations (Fig. 7). The increasing proportions of reduction products of 7-iso-jasmonic and jasmonic acids (isomeric cucurbic acids) observed between the Rhône River and the station R1 (Table 2) showed that LOX activity increased at the stations closest to the Rhône Mouth, not only in bacteria. but also in higher plant material.

\subsubsection{Induction of autoxidation in POM in estuarine waters}

The concentrations of isomeric cucurbic acids (resulting from $\mathrm{NaBH}_{4}$ reduction of 7-isojasmonic and jasmonic acids), after incubation for 102 days, increased significantly with increasing post incubation salinity (Table 3), attesting to the key role played by salinity in the induction of LOXs in riverine SPM. Indeed, 7-iso-jasmonic and jasmonic acids are specifically produced during LOX oxidation of $\alpha$-linolenic acid in higher plants (Kazan and Manners, 2008). Thus, the increase in LOX reactions observed at R1 and R7 (Fig. 7) can be attributed to the strong change in salinity between the Rhône (S $0 \mathrm{~g} / \mathrm{kg}$ ) and these off-shore stations ( $\mathrm{S} 33 \mathrm{~g} / \mathrm{kg}$ and $38 \mathrm{~g} / \mathrm{kg}$ at R1 and R7, respectively).

Interestingly, it is generally considered that LOXs play a central role in promoting oxidative injury in plants during environmental stress (Bhattachargee, 2014). Indeed, because the Fe present in LOXs is usually in the inactive ferrous $\mathrm{Fe}^{2+}$ state, an activation step is required for these enzymes to 
enter the catalytic cycle. This activation involves the reaction of the ferrous enzyme with FA hydroperoxides, producing an active ferric $\left(\mathrm{Fe}^{3+}\right)$ enzyme and an alkoxyl radical (Ivanov et al., 2005; Fig. 7). This generation of radicals in the course of the LOX catalytic cycle may also act like a catalyst in autoxidation (Fuch and Spiteller, 2014). Moreover, when LOX activity becomes very high, increasing amounts of free radicals may damage the active site of LOXs and release $\mathrm{Fe}^{2+}$ ions (Sato et al., 1992; Fuch and Spiteller, 2014), which may very efficiently catalyze the reduction of hydroperoxides to alkoxyl radicals (Schaich, 2005) and thereby induce free radical oxidation chains.

To explain the induction of autoxidation of TPOM observed in estuaries, we therefore propose the scenario in Fig. 8. Higher plant debris carried by rivers contains various amounts of hydroperoxides produced by photo- or autoxidation during the senescence of higher plants on land as well as inactive LOXs. When this material is delivered from rivers to coastal waters, the increase in salinity induces LOX activation, allowing additional production of FA hydroperoxides and alkoxyl radicals. The increase in the concentration of these free radicals can result to the following processes: (i) autoxidation of the components of higher plant debris and (ii) degradation of LOXs, resulting in the release of $\mathrm{Fe}^{2+}$ ions, which strongly enhance alkoxyl radical production and thus autoxidation. Accordingly, while it is well known that estuaries are reactive zones for the processing of OM (e.g. Bianchi, 2007), we contend that the role of autoxidation in these systems needs to be further examined as a potentially important process affecting the fate of TPOM.

\subsection{Arctic estuarine water}

\subsubsection{Enhancement of TPOM autoxidation}

The important role played by autoxidation in the degradation of TPOM in coastal waters, initially observed in the Mackenzie Estuary (Canadian Arctic) (Rontani et al., 2014a), was subsequently confirmed in the temperate zone of the Rhône Estuary (Galeron et al., 2017). The 
results demonstrated that the level of autoxidation in Arctic coastal waters was extraordinarily high. For example, autoxidation of 24-ethylcholest-5-en-3 $\beta$-ol (sitosterol) can reach 98\% in SPM from surface waters of the Beaufort Sea shelf (Rontani et al., 2014a), compared with only $10 \%$ of similar material in the Mediterranean Sea (Galeron et al., 2017). Moreover, autoxidation of specific biomarkers of vascular plants ( $\alpha$ - and $\beta$-amyrins and betulin) reached 99.8, 99.7 and 93.5\%, respectively in surface sediments from different regions of the Canadian Arctic (Rontani et al., 2017), while they appeared to be considerably lower in similar material collected from the Rhône Shelf (Table 4). In order to explain the high level of autoxidation in the Arctic, we compared several parameters (efficiency of photooxidation in terrestrial higher plant debris, hydroperoxide concentrations and LOX activity in river SPM) in the Mackenzie and Rhône rivers.

\subsubsection{Synergy between TPOM photo- and autoxidation}

Work has shown exceptional efficiency of type II (i.e. involving singlet oxygen) photosensitized oxidation in Arctic phytoplankton in summer (Rontani et al., 2012). In order to explain this unexpected efficiency, we recently carried out in vitro incubations of the diatom Chaetoceros neogracilis RCC2022 at different temperature and irradiance values. Interestingly, the results allowed us to show that type II photosensitized oxidation in senescent phytoplanktonic cells is strongly favored at low temperature and low irradiance (Amiraux et al., 2016). This apparent paradox has been attributed to: (i) the relative preservation of the sensitizer (chlorophyll) at low irradiance, which permits a longer production time for singlet oxygen, and (ii) the slower diffusion rate of singlet oxygen through the cell membranes at low temperature (Ehrenberg et al., 1998), thereby favoring the intracellular involvement of type II photosensitized reactions. Although never measured, enhanced photooxidation of the components of senescent higher plants in the Arctic thus seems likely. This is supported by a comparison between the photooxidation state of sitosterol (arising mainly from terrestrial vascular plants in the Mackenzie and Rhône rivers; Tolosa et al., 
2013; Galeron et al., 2015), which showed a greater extent of photooxidation in the Mackenzie River (48 $\pm 2 \%, \mathrm{n}=3$; Rontani et al., 2014) compared with the Rhône River $(10 \pm 1 \%, \mathrm{n}=30$; Galeron et al., 2015). It should be noted that in senescent cells photochemically produced hydroperoxides may undergo one electron reduction, which exacerbates peroxidative damage (Girotti, 1992). These processes result in the formation of alkoxyl radicals, which either directly or indirectly (Gardner, 1989) may initiate rounds of free radical peroxidation (autoxidation) by $\mathrm{H}$ abstraction. Intense autoxidation may thus be associated in some cases with strong photooxidation in senescent leaves of higher plants (Galeron et al., 2016a).

\subsubsection{Hydroperoxide induced LOX activation}

Due to the strongest photooxidation of higher plants in the Arctic, we predicted that SPM of the Mackenzie River should contain a higher proportion of hydroperoxides than in the Rhône River. In order to confirm this hypothesis, some hydroperoxides resulting from the oxidation of components of higher plants ( $\alpha$ - and $\beta$-amyrins; Galeron et al., 2016b) in SPM samples from the Rhône and Mackenzie rivers were quantified (Table 5). As predicted, the proportion of hydroperoxides (relative to the residual parent compound) was highest in SPM from the Mackenzie River. These results are particularly interesting due to the high specificity of these compounds (unambiguous tracers of higher plants; Otto et al., 2005; Volkman, 2006). They demonstrate that higher plant debris in the Mackenzie River contain a high proportion of hydroperoxides.

The molar ratio 5 cucurbic acids (resulting from the reduction of 7-iso-jasmonic and jasmonic acids during the treatment; Fig. 3)/parent $\alpha$-linolenic acid was more than three orders of magnitude higher in the Mackenzie River $(0.14 \pm 0.13)$ than in the Rhône River $\left(3.8 \pm 1.7 \times 10^{-5}\right.$; Table 2), which confirms greater activity of LOXs in the Mackenzie River particles containing a higher concentration of hydroperoxides (Table 5). This high LOX activation in the Arctic zone is also supported by the detection of threo 7,10-dihydroxyhexadec-8(E)-enoic acids (arising from $10 S$-DOX 
oxidation of palmitoleic acid and subsequent diol synthase activity, Fig. 6) in sediments from station M434 (Fig. 4a).

In Arctic zones (Fig. 9), due to enhanced photooxidation occurring during the senescence of terrestrial higher plants, the detritus from these organisms which are transferred to the rivers, contains a high proportion of hydroperoxides. These compounds strongly contribute to the activation of LOXs (particularly during the increase in salinity in estuarine waters). The resulting high LOX activity strongly enhances alkoxyl radical production (Fig. 8) and thereby autoxidation. In contrast, in temperate zones such as the Rhône River (Fig. 9) area, photooxidation in terrestrial higher plant detritus is more limited (Rontani et al., 2014b), probably due to the relatively high temperatures favoring migration of singlet oxygen outside the membranes (Ehrenberg et al., 1998). Consequently, higher plant debris in rivers contains only a moderate proportions of hydroperoxides. Under these conditions, activation of LOXs in estuarine waters is more limited and the induction of autoxidation less significant than in the Arctic. This hypothesis is supported by the strong differences in autoxidative reactivity previously observed during the incubation of SPM from the Rhône and Mackenzie rivers in seawater at room temperature. Indeed, the proportion of sitosterol autoxidation products increased from $2.6 \pm 0.4 \%$ to $10.6 \pm 0.7 \%$ after incubation of Rhône SPM for 49 days (Galeron et al., 2016c) and from $16.1 \pm 3.2 \%$ to $51.4 \pm 1.6 \%$ after incubation of Mackenzie SPM for 15 days (Rontani et al., 2014a).

\subsection{Tropical coastal waters}

\subsubsection{Role of autoxidation and photooxidation}

While the effect of both photo- and autoxidation seems less important in the Rhône than in the Mackenzie estuarine regions, it is reasonable to speculate that tropical areas should have even lower photooxidation and autoxidation rates, assuming a decreasing impact trend is linear. 
Examination of SPM samples from the Solimões and Madeira rivers, located in the central Amazon River basin. confirmed the low efficiency of photooxidative processes in this zone. Photooxidation is generally low in Amazon waters due to the high sediment load and low light penetration, accounting for $\leq 1 \%$ of $\mathrm{CO}_{2}$ emission from the basin (Amon and Benner, 1996; Remington et al., 2011). As sediments begin to settle along the lower Amazon River and nearshore plume, the potential for photooxidation then increases (Medeiros et al., 2015; Seidel et al., 2015). The low photooxidation state of sitosterol in SPM from the river shows that this process is also limited on land in senescent terrestrial higher plants. As discussed above, such results might seem paradoxical in these highly irradiated regions (solar irradiance ranging from 100 to $250 \mathrm{~W} / \mathrm{m}^{2}$ in the Amazon Basin; Pinker and Laszlo, 1992), but recent findings have shown that both high temperature and high irradiance increase the diffusion rate of singlet oxygen outside cell membranes and quickly consume the photosensitizer (Amiraux et al., 2016). The conjunction of the short lifespan of the photosensitizer, coupled with the high diffusion rate of singlet oxygen, results in the involvement of a weakly damaging photooxidative process. In contrast, autoxidation of vascular plant material appears to be strongly enhanced in the Amazon River (Section 3.3). This may be attributed to the high tropical temperature (avg. in the Amazon Basin, $26^{\circ} \mathrm{C}$ ) well known to favor homolytic cleavage of hydroperoxides (Chaiyasit et al., 2007) and thus initiation of free radical-induced oxidation (Schaich, 2005).

The high proportion (40-70\%) of sitostanol (relative to its parent sitosterol) contrasts with values generally considered typical of healthy phytoplanktonic cells (5-10\%; Wakeham et al., 1997). Such high values are generally attributed to the involvement of intense bacterial degradation (Wakeham et al., 1997), as previously observed in this river (Amon and Benner, 1996; Ward et al., 2013, 2016). Whereas photooxidation clearly appears to be the driving degradative force in riverine SPM from the Mackenzie River (Rontani et al., 2014a), autoxidation and biodegradation are the major processes at play in the tropical Amazon region. 
In order to estimate the involvement of LOX reactions, we also measured the molar ratio $\Sigma$ cucurbic acids/parent $\alpha$-linolenic acid in this material. The values $(0.20 \pm 0.17)$ are relatively close (Table 2) to those for the Mackenzie $(0.14 \pm 0.13)$, but still more than three orders of magnitude higher than in the Rhône $\left(3.8 \pm 1.7 \times 10^{-5}\right)$, confirming the highest LOX activation in Amazonian waters. These results allow us to draw a more precise degradation scenario for estuarine areas, whether tropical, temperate, or polar (Fig. 9). In tropical zones, photooxidation does not play a major role in the degradation of riverine SPM, for reasons discussed by Amiraux et al. (2016). However, the higher temperature seems to favor autoxidation, which is clearly the main driver in SPM degradation within the Amazon River, along with biodegradation (Amon and Benner, 1996; Ward et al., 2013). This intense autoxidation produces a large amount of hydroperoxides, favoring in turn important LOX activation in this river, which is able to induce intense autoxidation of TPOM in seawater (Fig. 8).

In order to test this assumption, we examined: (i) different surface sediment samples from the mouth of Amazon and in its northwest shelf (under the influence of the North Brazil Current; Sun et al., 2016) and (ii) SPM samples from its plume (Fig. 1). $\alpha$ - and $\beta$-Amyrins and betulin (unambiguous tracers of angiosperms; Otto et al., 2005) showed a clear increase in autoxidation state from the Amazon River to the sea (Table 4). It is interesting to note that the high extent of autoxidation observed in the Amazon shelf sediment samples (Table 4) was comparable with that recently observed in Arctic sediments (Rontani et al., 2017). The net increase in autoxidation state (Table 4) in SPM samples from A10 (S $0 \mathrm{~g} / \mathrm{kg})$ to $8(\mathrm{~S} 29.6 \mathrm{~g} / \mathrm{kg})$ confirmed the key role played by the increase in salinity in the induction of autoxidation. The participation of LOXs in this induction is supported by the presence of threo 7,10-dihydroxyhexadec-8(E)-enoic acids derived from initial attack of palmitoleic acid by 10S-DOX-like lipoxygenase (Guerrero et al., 1997; Busquets et al., 2004) at station A8 (Fig. 4b). 


\section{Conclusions}

Although autoxidation of TPOM has long been overlooked in coastal studies, recent findings demonstrating its importance have rekindled scientific interest in abiotic degradation across salinity gradients. Through the analysis of SPM samples from different rivers and estuaries at high and low latitude, we were able to confirm that autoxidation is favored in estuarine waters, and that its induction seems linked to LOX activation, which increases with salinity - a finding that support previous lab-based studies confirming an increase in LOX activity in $\mathrm{NaCl}$-supplemented medium. The LOX catalytic cycle itself, through the generation of radicals, may also induce autoxidative damage. The release of $\mathrm{Fe}^{2+}$, when the LOX activity is high enough that the radicals generated cause damage at the active site of LOX itself, could be another mechanism that induces autoxidation in estuarine waters.

The differences between estuaries, whether they are at high or low latitude, can be explained by the relative importance of each transformation process within the wider OM decay cycle across steep estuarine gradients. The low temperature and irradiance at high latitude favor photooxidative damage and in turn, hydroperoxide production. This high hydroperoxide content drives LOX activity and autoxidative damage in estuarine waters. At low latitude, photooxidation is less effective, but higher temperature and irradiance favor riverine autoxidation, which, through the production of hydroperoxides, also induces high LOX activation in estuarine waters. In temperate zones, riverine photooxidative and autoxidative damage, and hence hydroperoxide production are limited, causing the moderate increases observed in autoxidation and LOX activation in mixed waters.

The interactions between biotic and abiotic degradation processes appear to be critical in the overall carbon cycle in coastal systems, but further work is needed. It is interesting to note that autoxidation is not limited to lipids, carbohydrates and amino acids; it can also affect biopolymers (Schmid et al., 2007), lignin (Waggoner et al., 2015) and kerogen (Fookes and Walters, 1990), inducing ring opening and chain cleavage, which may then enhance mineralization of these generally 
considered recalcitrant substrates via priming (Bianchi, 2011). Thus, the ramifications of autoxidation/photoxidation processes appear to be quite important across a broader spectrum of important compounds found in the coastal zone and thus clearly warrant more attention.

Although the involvement of other radical production mechanisms cannot be totally excluded at this time, LOXs seem to play a key role in the induction of autoxidation in estuaries. Further studies will be needed to better understand the origins and induction mechanisms of these widespread enzymes across the aquatic continuum (Ward et al., 2017), from vascular plants to the streams, rivers, estuaries, and into the marine realm. Investigations of more systems across different latitudes, with different plant communities, light regimes and over multiple seasons are needed to better constrain the important biotic and abiotic drivers of these processes

\section{Acknowledments}

The work was supported by the LEFE-CYBER (Les Enveloppes Fluides et l'Environnement) national program, as part of the MORTIMER (Matière ORganique Terrestre rejetée par les fleuves et les rIvières en MER) research program. Thanks are due to the FEDER OCEANOMED for the funding of the apparatus employed. The work is also a contribution to the Labex OT-Med (through ANR-11-LABX-0061) funded by the French Government "Investissements d'Avenir" program of the French National Research Agency (ANR) through the A*MIDEX project (ANR-11-IDEX-000102). Additional data were provided by "MOOSE" (Mediterranean Oceanic Observing System for the Environment) with the support of the "Agence de l'Eau Rhône-Méditerranée-Corse”. Thanks are due to J. Bouchez for the donation of the SPM Amazon samples. Lower Amazon River samples were collected by Sawakuchi and Ward as part of FAPESP Grant \#08/58089-9 and National Science Foundation Grant \#1256724 (PI, J. Richey). We acknowledge GBMF-MMI Grants 2293 and 2928 and NSF-OCE-0934095 for the financial support provided to Amazon plume collections, as well as the Brazilian government (Ministério da Marinha). The Jon and Beverly Thompson Chair in 
Geological Sciences supported time for T.S.B. on this project. We are also grateful to S.T. Belt, G. Massé, A. Rochon and the officers and crew of the CCGS Amundsen for help with obtaining box core sediment material from the Beaufort Sea. Special thanks go to A. Delmont and M. Fornier for help collecting samples. Finally, we thank the two anonymous reviewers for their useful and constructive comments.

\section{Associate Editor - A. Pearson}

\section{References}

Aller, R.C., 1998. Mobile deltaic and continental shelf muds as suboxic, fluidized bed reactors. Marine Chemistry 61, 143-55.

Aller, R.C., Blair, N. E., Xia, Q., Rude, P.D., 1996. Remineralization rates, recycling, and storage of carbon in Amazon shelf sediments. Continental Shelf Research 16, 753-786.

Amiraux, R., Jeanthon, C., Vaultier, F., Rontani, J.-F., 2016. Paradoxical effects of temperature and solar irradiance on the photodegradation state of killed phytoplankton. Journal of Phycology 52, $475-485$.

Amon, R.M.W., Benner, R., 1996 Photochemical and microbial consumption of dissolved organic carbon and dissolved oxygen in the Amazon River system. Geochimica et Cosmochimica Acta 60, $1783-1792$.

Bhattacharjee, S., 2014. Membrane lipid peroxidation and its conflict of interest: the two faces of oxidative stress. Current Science 107, 1811-1823.

Bianchi, T.S., 2007. Biogeochemistry of Estuaries. Oxford University Press, Oxford, 720 pp.

Bianchi, T.S., 2011. The role of terrestrially derived organic carbon in the coastal ocean: A changing paradigm and the priming effect. Proceedings of the National Academy of Sciences 108, 19,47319,481 . 
Bourgeois, S., Pruski, A.M., Sun, M.-Y., Buscail, R., Lantoine, F., Vétion, G., Rivière, B., Charles, F., 2011. Distribution and lability of land-derived organic matter in the surface sediments of the Rhône prodelta and the adjacent shelf (Mediterranean Sea, France): a multi proxy study. Biogeosciences 8, 3107-3125.

Bridson, J.N., 1985. Lipid fraction in forest litter: early stages of decomposition. Soil Biology and Biochemistry 17, 285-290.

Busquets, M., Deroncelé, V., Vidal-Mas, J., Rodríguez, E., Guerrero, A., Manresa, A., 2004. Isolation and characterization of a lipoxygenase from Pseudomonas. Antonie van Leeuwenhoek $85,129-139$.

Chaiyasit, W., Elias, R.J., McClements, D.J., Decker, E.A., 2007. Role of physical structures in bulk oils on lipid oxidation. Critical Revue of Food Science 47, 299-317.

Christodoulou, S., Marty, J.-C., Miquel, J.-C., Volkman, J.K., Rontani, J.-F., 2009. Use of lipids and their degradation products as biomarkers for carbon cycling in the northwestern Mediterranean Sea. Marine Chemistry 113, 25-40.

de Leeuw, J.W., Largeau, C., 1993. A review of macromolecular organic compounds that comprise living organisms and their role in kerogen, coal, and petroleum formation. Organic Geochemistry $11,23-72$.

Doxaran, D., Devred, E., Babin, M., 2015. A $50 \%$ increase in the mass of terrestrial particles delivered by the Mackenzie River into the Beaufort Sea (Canadian Arctic Ocean) over the last 10 years. Biogeosciences 12, 3551-3565.

Ehrenberg, B., Anderson, J.L., Foote, C.S., 1998. Kinetics and yield of singlet oxygen photosensitized by hypericin in organic and biological media. Photochemistry and Photobiology $68,135-140$. 
Fichot, C.G., Kaiser, K., Hooker, S.B., Amon, R.M.W., Babin, M., Bélanger, S., Walker, S.A., Benner, R., 2013. Pan-Arctic distributions of continental runoff in the Arctic Ocean. Science Reports 3, 1053.

Fookes, J.R., Walters, C.K., 1990. A chemical investigation of shale oil ageing. Fuel 69, 1105-1108.

Fossey, J., Lefort, D., Sorba, J., 1995. Free Radicals in Organic Chemistry. Masson, Paris.

Frankel, E.N., 1980. Lipid oxidation. Progress in Lipid Research 19, 1-22.

Frankel, E.N., 1998. Lipid Oxidation. The Oily Press, Dundee.

Fuchs, C., Spiteller, G., 2014. Iron release from the active site of lipoxygenase. Zeitschrift für Naturforschung C 55, 643-648.

Galeron, M.-A., Amiraux, R., Charriere, B., Radakovitch, O., Raimbault, P., Garcia, N., Lagadec, V., Vaultier, F., Rontani, J.-F., 2015. Seasonal survey of the composition and degradation state of particulate organic matter in the Rhône River using lipid tracers. Biogeosciences 12, 1431-1446.

Galeron, M.-A., Volkman, J.K., Rontani, J.-F., 2016a. Oxidation products of betulin: New tracers of abiotic degradation of higher plant material in the environment. Organic Geochemistry 91, 31-42.

Galeron, M.-A., Vaultier, F., Rontani, J.-F., 2016b. Oxidation products of $\alpha$ - and $\beta$-amyrins: potential tracers of abiotic degradation of vascular-plant organic matter in aquatic environments. Environmental Chemistry 13, 732-744.

Galeron, M.-A., Radakovitch, O., Charriere, B., Rontani, J.-F., 2016c. Metal ions and hydroperoxide content: main drivers of coastal lipid autoxidation in riverine suspended particulate matter and higher plant debris. Journal of Marine Science and Engineering doi. 10.3390/jmse4030050.

Galeron, M.-A., Radakovitch, O., Charrière, B., Vaultier, F., Rontani, J.-F., 2017. Impacts of coastal degradative processes: autoxidation a major player in the fate of terrestrial particulate organic matter in seawater. Journal of Geophysical Research - Biogeosciences 122, 1203-1215.

Gardner, H.W., 1989. Oxygen radical chemistry of polyunsaturated fatty acids. Free Radical Biology and Medicine 7, 65-86. 
Gardner, H.W., Hou, C.T., 1999. All (S) stereoconfiguration of 7,10-dihydroxy-8(E)-octadecenoic acid from bioconversion of oleic acid by Pseudomonas aeruginosa. Journal of the American Chemical Society 76, 1151-1156.

Garreta, A., Val-Moraes, S.P., García-Fernández, Q., Busquets, M., Juan, C., Oliver, A., Ortiz, A., Gaffney, B.J., Fita I., Manresa, A., Carpena, X., 2016. Structure and interaction with phospholipids of a prokaryotic lipoxygenase from Pseudomonas aeruginosa. FASEB Journal 27, $4811-4821$.

Girotti, A.W., 1992. New trends in photobiology. Journal of Photochemistry and Photobiology B 13, $105-118$.

Girotti, A.W., 1998. Lipid hydroperoxide generation, turnover, and effector action in biological systems. Journal of Lipid Research 39, 1529-1542.

Goulding, M., Barthem, R., Ferreira, E., 2003. The Smithsonian Atlas of the Amazon. Smithsonian Books, Washington and London.

Guerrero, A., Casals, I., Busquets, M., Leon, Y., Manresa, A., 1997. Oxidation of oleic acid to (E)10-hydroperoxy-8-octadecenoic and (E)-10-hydroxy-8-octadecenoic acids by Pseudomonas sp. 42A2. Biochimica et Biophysica Acta - Lipids and Lipid Metabolism 1347, 75-81.

Hathway, D.E., Seakins, J.W.T., 1957. Autoxidation of polyphenols. Part III. Autoxidation in neutral aqueous solution of flavans related to catechin. Journal of the Chemical Society pp 1562-1566.

Hedges, J.I., Clark, W.A., Quay, P.D., Richey, J.E., Devol, A.H., Santos, U.D.M, 1986. Compositions and fluxes of particulate organic material in the Amazon River, Limnology and Oceanography 31, 717-738.

Hedges, J.I., Keil, R.G., 1995. Sedimentary organic matter preservation: an assessment and speculative synthesis. Marine Chemistry 49, 81-115.

Hedges, J.I., Keil, R.G., Benner, R., 1997. What happens to terrestrial organic matter in the ocean? Organic Geochemistry 27, 195-212. 
Hilton, R.G., Galy, V., Gaillardet, J., Dellinger, M., Bryant, C., O’Regan, M., Gröcke, D.R., Coxall, H., Bouchez, J., Calmels, D., 2015. Erosion of organic carbon in the Arctic as a geological carbon dioxide sink. Nature 524, 84-87.

Ivanov, I., Saam, J., Kuhn, H., Holzhütter, H.-G., 2005. Dual role of oxygen during lipoxygenase reactions. FEBS Journal 272, 2523-2535.

Jernerén, F., Garscha, U., Hoffmann, I., Hamberg, M., Oliw, E.H., 2010. Reaction mechanism of 5,8-linoleate diol synthase, 10R-dioxygenase and 8,11-hydroperoxide isomerase of Aspergillus clavatus. Biochimica et Biophysica Acta 1801, 503-507.

Jones, D.M., Carter, J.F., Eglinton, G., Jumeau, E.J. Fenwick, C.S., 1991. Determination of $\delta^{13}$ C values of sedimentary straight chain and cyclic alcohols by gas chromatography/isotope ratio mass spectrometry. Biological Mass Spectrometry 20, 641-646.

Karlsson, E.S., Charkin, A., Dudarev, O., Semiletov, I., Vonk, J.E., Sánchez-García, L., Andersson, A., Gustafsson, Ö., 2011. Carbon isotopes and lipid biomarker investigation of sources, transport and degradation of terrestrial organic matter in the Buor-Khaya Bay, SE Laptev Sea.

Biogeosciences 8, 1865-1879.

Kazan, K., Manners, J.M., 2008. Jasmonate signaling: toward an integrated view. Plant Physiology $146,1459-1468$.

Kim, H., Gardner, H.W., Hou, C.T., 2000. 10(S)-Hydroxy-8(E)-octadecenoic acid, an intermediate in the conversion of oleic acid to 7,10-dihydroxy-8(E)-octadecenoic acid. Journal of the American Oil Chemical Society 77, 95-99.

Kug, J.-S., Jeong, J.-H., Jang, Y.-S., Kim, B.-M., Folland, C.K., Min, S.-K., Son, S.-W., 2015. Two distinct influences of Arctic warming on cold winters over North America and East Asia. Nature Geoscience 8, 759-762.

Lawrence, G.D., Mavi, A., Meral, K., 2008. Promotion by phosphate of Fe(III)- and Cu(II)-catalyzed autoxidation of fructose. Carbohydrate Research 343, 626-635. 
Lentz, S.J., 1995. Seasonal variations in the horizontal structure of the Amazon Plume inferred from historical hydrographic data, Journal os Geophysical Research 100, 2391-2400.

Macdonald, R.W., Solomon, S.M., Cranston, R.E., Welch, H.E., Yunker, M.B., Gobeil, C., 1998. A sediment and organic carbon budget for the Canadian Beaufort Shelf. Marine Geology 144, 255273.

Marchand, D., Rontani, J.-F., 2001. Characterisation of photo-oxidation and autoxidation products of phytoplanktonic monounsaturated fatty acids in marine particulate matter and recent sediments. Organic Geochemistry 32, 287-304.

Martínez, E., Hamberg, M., Busquets, M., Díaz, P., Manresa, A., Oliw, E.H., 2010. Biochemical characterization of the oxygenation of unsaturated fatty acids by the dioxygenase and hydroperoxide isomerase of Pseudomonas aeruginosa 42A2. Journal of Biological Chemistry 285, 9339-9345.

Mayer, L.M., Chick, L.L., Allison, M.A., 2008. Input of nutritionally rich organic matter from the Mississippi River to the Louisiana coastal zone. Estuaries and Coasts 31, 1052-1062.

Medeiros, P.M., Seidel, M., Ward, N.D., Carpenter, E.J., Gomes, H.R., Niggemann, J., Krusche, A.V., Richey, J.E., Yager, P.L., Dittmar, T., 2015 Fate of the Amazon River dissolved organic matter in the tropical Atlantic Ocean. Global Biogeochemical Cycles 29, 677-690.

Mittova, V., Tal, M., Volokita, M., Guy, M., 2002. Salt stress induces up-regulation of an efficient chloroplast antioxidant system in the salt-tolerant wild tomato species Lycopersicon pennellii but not in the cultivated species. Physiologia Plantarum 115, 393-400.

Moreira-Turcq, P., Bonnet, M.P., Amorim, M., Bernardes, M., Lagane, C., Maurice, L., Perez, M., Seyler, P., 2013. Seasonal variability in concentration, composition, age, and fluxes of particulate organic carbon exchanged between the floodplain and Amazon River. Global Biogeochemical Cycles 27, 119-130. 
Otto, A., Shunthirasingham, C., Simpson, M.J., 2005. A comparison of plant and microbial biomarkers in grassland soils from the Prairie Ecozone of Canada. Organic Geochemistry 36, $425-448$.

Pinker, R.T., Laszlo, I., 1992. Interannual variability of solar irradiance over the Amazon Basin including the 1982-83 El Niño Year. Journal of Climate 5, 1305-1315.

Pokorny, J., 1987. Major factors affecting the autoxidation of lipids. In: Chan, H. (Ed.), Autoxidation of Unsaturated Lipids. Academic Press, London, pp. 141-206.

Porter, N.A., Caldwell, S.E., Mills, K.A., 1995. Mechanisms of free radical oxidation of unsaturated lipids. Lipids 30, 277-290.

Remington, S., Krusche, A., Richey, J., 2011. Effects of DOM photochemistry on bacterial metabolism and $\mathrm{CO}_{2}$ evasion during falling water in a humic and a whitewater river in the Brazilian Amazon. Biogeochemistry 105, 185-200.

Rodriguez-Rosales, M.P., Kerkeb, L., Bueno, P., Donaire, J.P., 1999. Changes induced by NaCl in lipid content and composition, lipoxygenase, plasma membrane $\mathrm{H}^{+}$-ATPase and antioxidant enzyme activities of tomato (Lycopersicon esculentum Mill) calli. Plant Science 143, 143-150.

Rontani, J.-F., 2012. Photo-and free radical-mediated oxidation of lipid components during the senescence of phototrophic organisms. In: Nagata, T. (Ed.), Senescence. Intech, Rijeka, pp. 3-31.

Rontani, J.-F., Rabourdin, A., Marchand, D., Aubert, C., 2003. Photochemical oxidation and autoxidation of chlorophyll phytyl side chain in senescent phytoplanktonic cells: Potential sources of several acyclic isoprenoid compounds in the marine environment. Lipids 38, 241-254.

Rontani, J.-F., Zabeti, N., Wakeham, S.G., 2009. The fate of marine lipids: Biotic vs. abiotic degradation of particulate sterols and alkenones in the Northwestern Mediterranean Sea. Marine Chemistry $113,9-18$.

Rontani, J.-F., Charrière, B., Forest, A., Heussner, S., Vaultier, F., Petit, M., Delsaut, N., Fortier, L., Sempéré, R., 2012. Intense photooxidative degradation of planktonic and bacterial lipids in 
sinking particles collected with sediment traps across the Canadian Beaufort Shelf (Arctic Ocean). Biogeosciences 9, 4787-4802.

Rontani, J.-F., Charrière, B., Sempéré, R., Doxaran, D., Vaultier, F., Vonk, J.E., Volkman, J.K., 2014a. Degradation of sterols and terrigenous organic matter in waters of the Mackenzie Shelf, Canadian Arctic. Organic Geochemistry 75, 61-73.

Rontani, J.-F., Vaultier, F., Bonin, P., 2014b. Biotic and abiotic degradation of marine and terrestrial higher plant material in intertidal surface sediments from Arcachon Bay (France): A lipid approach. Marine Chemistry 158, 69-79.

Rontani, J.-F., Aubert, C., Belt, S.T., 2015. EIMS fragmentation pathways and MRM quantification of $7 \alpha / \beta$-hydroxy-dehydroabietic acid TMS derivatives. Journal of the American Society for Mass Spectrometry 26, 1606-1616.

Rontani, J.-F., Galeron, M-A., Aubert, C., 2016. EIMS Fragmentation and MRM quantification of TMS derivatives of cucurbic acid and its 6,7-stereoisomers. Rapid Communications in Mass Spectrometry 30, 2253-2264.

Rontani, J.-F., Galeron, M.-A., Amiraux, R., Artigue, L., Belt, S.T., 2017. Identification of di- and triterpenoid lipid tracers confirms the significant role of autoxidation in the degradation of terrestrial vascular plant material in the Canadian Arctic. Organic Geochemistry 108, 43-50.

Sadaoui, M., Ludwig, W., Bourrin, F., Raimbault, P., 2016. Controls, budgets and variability of riverine sediment fluxes to the Gulf of Lions (NW Mediterranean Sea). Journal of Hydrology 540, $1002-1015$

Sampere, T.P., Bianchi, T.S., Wakeham, S.G., Allison, M.A., 2008. Sources of organic matter in surface sediments of the Louisiana Continental Margin: Effects of primary depositional/transport pathways and a hurricane Event. Continental Shelf Research 28, 2472-2487. 
Sato, K., Akaike, T., Kohno, M., Ando, M., Maeda, H., 1992. Hydroxyl radical production by $\mathrm{H}_{2} \mathrm{O}_{2}$ plus $\mathrm{Cu}, \mathrm{Zn}$-superoxide dismutase reflects the activity of free copper released from the oxidatively damaged enzyme. Journal of Biological Chemistry 267, 25371-25377.

Schaich, K.M., 2005. Lipid oxidation: Theoretical aspects. In: Shahidi, F. (Ed.), Bailey’s Industrial Oil and Fat Products. John Wiley \& Sons, Chichester, pp. 269-355.

Schmid, M., Ritter, A., Grubelnik, A., Zinn, M., 2007. Autoxidation of medium chain length polyhydroxyalkanoate. Biomacromolecules $8,579-584$.

Schmidt, M.W.I., Torn, M.S., Abiven, S., Dittmar, T., Guggenberger, G., Janssens, I.A., Kleber, M., Kögel-Knabner, I., Lehmann, J., Manning, D.A.C., Nannipieri, P., Rasse, D.P., Weiner, S., Trumbore, S.E., 2011. Persistence of soil organic matter as an ecosystem property. Nature 478, 49-56.

Seidel, M., Yager, P.L., Ward, N.D., Carpenter, E.J., Gomes, H.R., Krusche, A.V., Richey, J.E., Dittmar, T., Medeiros, P.M., 2015. Molecular-level changes of dissolved organic matter along the Amazon river-to-ocean continuum. Marine Chemistry 177, 218-231.

Seko, H., Tsuge, K., Igashira-Kamiyama, A., Kawamoto, T., Konno, T., 2010. Autoxidation of thiolcontaining amino acid to its disulfide derivative that links two copper(II) centers: the important role of auxiliary ligand. Chemical Communications 46, 1962-1964.

Sempéré, R., Charrière, B., Van Wambeke, F., Cauwet, G., 2000. Carbon inputs of the Rhône River to the Mediterranean Sea: Biogeochemical implications. Global Biogeochemical Cycles 14, 669681.

Sicre, M.-A., Paillasseur, J.-L., Marty, J.-C., Saliot, A., 1988. Characterization of seawater samples using chemometric methods applied to biomarker fatty acids. Organic Geochemistry 12, 281-288.

Siedow, J.N., 1991. Plant lipoxygenase: Structure and function. Annual Reviews of Plant Physiology $42,145-188$. 
Suh, M.-J., Baek, K.-Y., Kim, B.-S., Hou, C.T., Kim, H.R., 2011. Production of 7,10-dihydroxy8(E)-octadecenoic acid from olive oil by Pseudomonas aeruginosa PR3. Applied Microbiology Biotechnology 89, 1721-1727.

Sun, S., Schefu, E., Mulitza, S., Chiessi, C.M., Sawakuchi, A.O., Zabel, M., Baker, P.A., Hefter, J., Mollenhauer, G., 2016. Origin and processing of terrestrial organic carbon in the Amazon system: lignin phenols in river, shelf and fan sediments. Biogeosciences Discussions doi: 10.5194/bg2016-468.

Thompson, J.E., Legge, R.L., Barber, R.F., 1987. The role of free radicals in senescence and wounding. New Phytologist 105, 317-344.

Tolosa, I., Fiorini, S., Gasser, B., Martín, J., Miquel, J.-C., 2013. Carbon sources in suspended particles and surface sediments from the Beaufort Sea revealed by molecular lipid biomarkers and compound-specific isotope analysis. Biogeosciences 10, 2061-2087.

Volkman, J.K., 2003. Sterols in microorganisms. Applied Microbiology and Biotechnology 60, 495506.

van Dongen, B.E., Zencak, Z., Gustafsson, Ö., 2008. Differential transport and degradation of bulk organic carbon and specific terrestrial biomarkers in the surface waters of a sub-arctic brackish bay mixing zone. Marine Chemistry 112, 203-214.

Volkman, J.K., 2006. Lipid markers for marine organic matter. In: Volkman, J.K. (Ed.), Marine Organic Matter: Biomarkers, Isotopes and DNA. Springer, Heidelberg, pp. 27-70.

Vonk, J.E., Sanchez-Garcia, L., Semiletov, I.P., Dudarev, O.V., Eglinton, T.I., Andersson, A., Gustafsson, Ö., 2010. Molecular and radiocarbon constraints on sources and degradation of terrestrial organic carbon along the Kolyma paleoriver transect, East Siberian Sea. Biogeosciences 7, 3153-3166. 
Waggoner, D.C., Chen, H., Willoughby, A.S., Hatcher, P.G., 2015. Formation of black carbon-like and acyclic aliphatic compounds by hydroxyl radical initiated degradation of lignin. Organic Geochemistry 82, 69-76.

Wakeham, S.G., Canuel, E.A., 2006. Degradation and preservation of organic matter in marine sediments. In: Volkman, J.K. (Ed.), Marine Organic Matter: Biomarkers, Isotopes and DNA. Springer, Heidelberg, pp. 295-321.

Wakeham, S.G., Hedges, J.I., Lee, C., Peterson, M.L., Hernes, P.J., 1997. Compositions and transport of lipid biomarkers through the water column and surficial sediments of the EqPac Ocean, Deep-Sea Research 44, 2131-2162.

Ward, N.D., Keil, R.G., Medeiros, P.M., Brito, D.C., Cunha, A.C., Dittmar, T., Yager, P.L., Krusche, A.V., Richey, J.E., 2013. Degradation of terrestrially derived macromolecules in the Amazon River. Nature Geoscience 6, 530-533.

Ward, N.D., Krusche, A.V., Sawakuchi, H.O., Brito, D.C., Cunha, A.C., Moura, J.M.S., da Silva, R., Yager, P.L., Keil, R.G., Richey, J.E., 2015. The compositional evolution of dissolved and particulate organic matter along the lower Amazon River-Óbidos to the ocean. Marine Chemistry $177,244-256$.

Ward, N.D., Bianchi, T.S., Sawakuchi, H.O., Gagne-Maynard, W., Cunha, A.C., Brito, D.C., Neu, V., Valerio, A.M., da Silva, R., Krusche, A.V., Richey, J.E., Keil, R.G., 2016. The reactivity of plant-derived organic matter and the potential importance of priming effects in the lower Amazon River. Journal of Geophysical Research: Biogeosciences 121, 1522-1539.

Ward, N.D., Bianchi, T.S., Medeiros, P.M., Seidel, M., Richey, J.E., Keil, R.G., Sawakuchi, H.O., 2017. Where carbon goes when water flows: carbon cycling across the aquatic continuum. Frontiers in Marine Sciences 4, 7. 
Zhang, L., Zhang, G., Wang, Y., Zhou, Z., Meng, Y., Chen, B., 2012. Effect of soil salinity on physiological characteristics of functional leaves of cotton plants. Journal of Plant Research 126, 293-304. 


\section{Figure captions}

Fig. 1. Summary map showing sampling locations: (A) Rhône River and shelf, (B) Amazon River and Shelf and (C) Mackenzie River and shelf.

Fig. 2. Partial $m / z$ 199.1518, 213.1635, 329.1968, 343.2125, 225.1670, 315.2171, 327.1807

chromatograms showing presence of oxidation products of palmitoleic acid in SPM sample collected

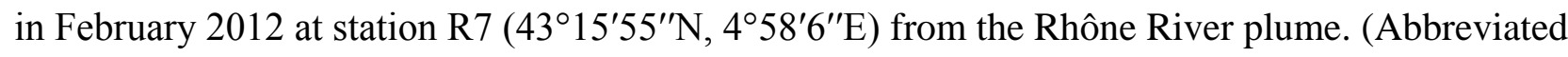
names: e.g. 10-hydroxyC16:1 $\triangle 8 E \mathrm{FA}=10$-hydroxyhexadec-8(E)-enoic acid)

Fig. 3. Degradation of linolenic acid by 13-lipoxygenase.

Fig. 4. Partial $m / z$ 225.1670, 315.2171, 327.1807, 487.3090 chromatograms showing presence of 7,10-dihydroxyhexadec-8(E)-enoic acid in: (A) surface sediment from the Mackenzie River plume (Station M434) $\left(70^{\circ} 10^{\prime} 12^{\prime \prime} \mathrm{N}, 133^{\circ} 35^{\prime} 24^{\prime \prime} \mathrm{W}\right)$ and (B) in SPM from station A8 (02 $35^{\prime} 30^{\prime \prime} \mathrm{S}$, 49 $38^{\prime} 55^{\prime \prime} \mathrm{W}$ ) in the Amazon Estuary. (Abbreviated name: 7,10-dihydroxyC $16: 1 \triangle 8 E \mathrm{FA}=7,10$ dihydroxyhexadec-8(E)-enoic acid)

Fig. 5. MRM chromatograms $(\mathrm{m} / \mathrm{z}, 266 \rightarrow 134$ and $\mathrm{m} / \mathrm{z}, 335 \rightarrow 93)$ showing proportions of isomeric cucurbic acids and their parent linolenic acid in SPM samples collected from station Tsiigehtchic $\left(67^{\circ} 27^{\prime} 7^{\prime \prime} \mathrm{N}, 133^{\circ} 45^{\prime} 33^{\prime \prime} \mathrm{W}\right)$ in the Mackenzie River.

Fig. 6. Main products resulting from oxidation of palmitoleic acid by $10 S$-DOX-like lipoxygenase. 
Fig. 7. Estimation of part played by autoxidation, photooxidation and lipoxygenase in the degradation of palmitoleic acid in SPM samples collected in February 2012 along a transect in the Rhône River plume (average of triplicates).

Fig. 8. Proposed pathways for lipoxygenase-induced autoxidative degradation of terrestrial higher plant material discharged by rivers to seawater.

Fig. 9. Degradation of terrestrial higher plant material discharged by rivers in Arctic, temperate and tropical zones. 


\section{Table 1}

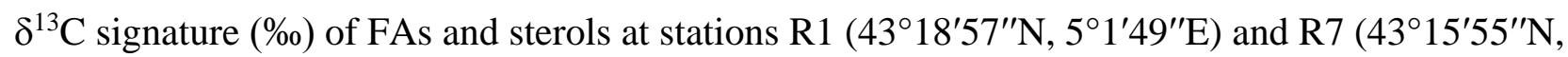
$\left.4^{\circ} 58^{\prime} 6^{\prime \prime} \mathrm{E}\right)$ in the Rhône River plume.

$\begin{array}{lll}\text { Compounds } & \text { Station R1 } & \text { Station R7 }\end{array}$

$\mathrm{C}_{14: 0} \mathrm{FA}$

Branched $\mathrm{C}_{15: 0} \mathrm{FAs}$

$\mathrm{C}_{16: 1 \Delta 9} \mathrm{FA}$

$\mathrm{C}_{16: 0} \mathrm{FA}$

$\mathrm{C}_{18: 1 \Delta 9} \mathrm{FA}$

$\mathrm{C}_{18: 1 \Delta 11} \mathrm{FA}$

$\mathrm{C}_{18: 0} \mathrm{FA}$

Cholesterol

24-Methylenecholesterol

Sitosterol
$-28.6 \pm 1.0^{\mathrm{a}}$

$-\mathrm{b}$

$-30.9 \pm 0.4$

$-27.8 \pm 1.1$

$-28.0 \pm 0.2$

$-30.4 \pm 0.2$

$-29.5 \pm 0.7$

$-28.6 \pm 1.1$

$-25.6 \pm 0.4$

$-29.2 \pm 1.6$

$-20.6 \pm 0.5$

$-23.6 \pm 0.6$

$-21.6 \pm 1.4$

$-27.1 \pm 2.2$

a Analytical error; $^{\mathrm{b}}$ not measured (below detection limit). 


\section{Table 2}

Proportions of isomeric cucurbic acids and their parent linolenic acid in SPM samples from the Rhône River and shelf and the Amazon and Mackenzie rivers.

Sample $\quad$ Location
$\begin{gathered}\text { cucurbic acids/parent } \alpha- \\ \text { linolenic } \text { acid }^{\mathrm{a}}\end{gathered}$

$\begin{array}{lcc}\text { SPM Rhône Shelf (station R1) } & \left(43^{\circ} 18^{\prime} 57^{\prime \prime} \mathrm{N}, 5^{\circ} 1^{\prime} 49^{\prime \prime} \mathrm{E}\right) & 3.1 \pm 2.2 \times 10^{-3} \\ \text { SPM Rhône River } & \left(43^{\circ} 40^{\prime} 44^{\prime \prime} \mathrm{N}, 4^{\circ} 37^{\prime} 16^{\prime \prime} \mathrm{E}\right) & 3.8 \pm 1.7 \times 10^{-5} \\ \text { SPM Mackenzie River } & \left(67^{\circ} 27^{\prime} 7^{\prime \prime} \mathrm{N}, 133^{\circ} 45^{\prime} 32^{\prime \prime} \mathrm{W}\right) & 0.14 \pm 0.13 \\ \text { SPM Amazon River } & \left(03^{\circ} 27^{\prime} 24^{\prime \prime} \mathrm{N}, 58^{\circ} 47^{\prime} 57^{\prime \prime} \mathrm{W}\right) & 0.20 \pm 0.17\end{array}$

${ }^{a}$ Averages of triplicates. 


\section{Table 3}

Production of isomeric cucurbic acids (from $\mathrm{NaBH}_{4}$ reduction of jasmonic acids during the treatment) after incubation of SPM from the Rhône River at different salinity values for 102 days.

\begin{tabular}{ccc}
\hline $\begin{array}{c}\text { Post incubation salinity } \\
(\mathrm{g} / \mathrm{kg})\end{array}$ & $\begin{array}{c}\text { 7-iso-cucurbic acid } \\
(\mathrm{ng} / \mathrm{g} \text { dry wt })\end{array}$ & $\begin{array}{c}\text { 6-epi-7-iso-cucurbic acid } \\
(\mathrm{ng} / \mathrm{g} \text { dry wt })^{\mathrm{a}}\end{array}$ \\
\hline 0 & $0.12 \pm 0.07^{\mathrm{a}}$ & $2.64 \pm 0.30^{\mathrm{a}}$ \\
15 & $0.30 \pm 0.10^{\mathrm{a}}$ & $4.00 \pm 0.70^{\mathrm{a}}$ \\
25 & $0.79 \pm 0.13^{\mathrm{a}}$ & $13.8 \pm 4.9^{\mathrm{a}}$ \\
\hline
\end{tabular}

${ }^{\text {a }}$ Average of triplicates. 


\section{Table 4}

Autoxidation of vascular plant lipid tracers (betulin and amyrins) in surface sediment $(0-1 \mathrm{~cm})$ and SPM samples from the Amazon River, fan and shelf and in surface sediment $(0-1 \mathrm{~cm})$ from the Rhône shelf (nd, not detected).

Sample

Location

Betulin autoxidation

$(\%)$

\section{Amazon}

Surface sediment (Almeirim)

$\left(01^{\circ} 34^{\prime} 428^{\prime \prime} \mathrm{S}, 52^{\circ} 40^{\prime} 79^{\prime \prime} \mathrm{W}\right)$

26.9

Surface sediment (Macapá south channel)

$\left(00^{\circ} 09^{\prime} 249^{\prime \prime} \mathrm{S}, 51^{\circ} 03^{\prime} 120^{\prime \prime} \mathrm{W}\right)$

nd

$\left(00^{\circ} 05^{\prime} 240^{\prime \prime} \mathrm{S}, 50^{\circ} 37^{\prime} 212^{\prime \prime} \mathrm{W}\right)$

nd

Surface sediment (Macapá north channel)

$\left(01^{\circ} 20^{\prime} 26^{\prime \prime} \mathrm{S}, 4^{\circ} 22^{\prime} 20^{\prime \prime} \mathrm{W}\right)$

85.6

SPM (station A8)

$\left(02^{\circ} 35^{\prime} 30^{\prime \prime} \mathrm{S}, 49^{\circ} 38^{\prime} 55^{\prime \prime} \mathrm{W}\right)$

94.5

Surface sediment (station A13)

(07 $\left.57^{\prime} 7^{\prime \prime} \mathrm{S}, 51^{\circ} 19^{\prime} 40^{\prime \prime} \mathrm{W}\right)$

94.2

Surface sediment (station A19)

$\left(06^{\circ} 48^{\prime} 52^{\prime \prime} \mathrm{S}, 46^{\circ} 02^{\prime} 02^{\prime \prime} \mathrm{W}\right)$

91.0

Surface sediment (station A28)

$\left(09^{\circ} 00^{\prime} 5^{\prime \prime} \mathrm{S}, 49^{\circ} 59^{\prime} 59^{\prime \prime} \mathrm{W}\right)$

93.5

Rhône

Surface sediment (station R28) 


\section{Table 5}

Proportion of hydroperoxyl amyrins (relative to residual parent compound) of SPM from Rhône, Mackenzie and Amazon rivers.

$11 \alpha$-Hydroperoxy- $\alpha$-amyrin $\quad 11 \alpha$-Hydroperoxy- $\beta$-amyrin

Rhône (4340'44"N, 4³7'16"'W; Feb. 2012)

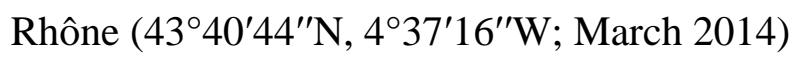

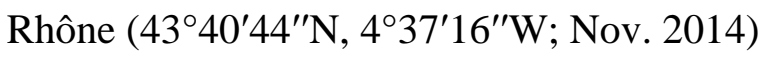

Mackenzie $\left(67^{\circ} 27^{\prime} 7^{\prime} \mathrm{N}, 133^{\circ} 45^{\prime} 32^{\prime \prime} \mathrm{W}\right.$; June 2011)

Amazon $\left(03^{\circ} 19^{\prime} 29^{\prime \prime} \mathrm{N}, 60^{\circ} 32^{\prime} 58^{\prime \prime} \mathrm{W}\right.$; June 2005)

Amazon $\left(03^{\circ} 19^{\prime} 29^{\prime \prime} \mathrm{N}, 60^{\circ} 32^{\prime} 58^{\prime \prime} \mathrm{W}\right.$; June 2006)

Amazon $\left(03^{\circ} 27^{\prime} 24^{\prime \prime} \mathrm{N}, 58^{\circ} 47^{\prime} 57^{\prime \prime} \mathrm{W}\right.$; June 2005)

$$
20.7 \pm 6.2^{\mathrm{a}, \mathrm{b}, \mathrm{c}}
$$

$6.3 \pm 1.8^{\mathrm{a}, \mathrm{b}, \mathrm{c}}$

$$
7.5 \pm 0.3^{\mathrm{b}, \mathrm{c}}
$$$$
20.4 \pm 0.2^{b, c}
$$$$
70.9 \pm 21.6^{\mathrm{a}, \mathrm{c}}
$$$$
6.8 \pm 0.4^{\mathrm{b}, \mathrm{c}}
$$$$
9.4 \pm 1.3^{\mathrm{b}, \mathrm{c}}
$$$$
25.2 \pm 6.8^{\mathrm{a}, \mathrm{c}}
$$

$75.9 \pm 1.7^{\mathrm{a}, \mathrm{d}}$

$70.8 \pm 6.8^{\mathrm{a}, \mathrm{d}}$

$72.0 \pm 1.2^{\mathrm{a}, \mathrm{d}}$

$74.8 \pm 1.0^{\mathrm{a}, \mathrm{d}}$
$67.7 \pm 9.9^{\mathrm{a}, \mathrm{d}}$

$71.4 \pm 0.4^{\mathrm{a}, \mathrm{d}}$

${ }^{\mathrm{a}}$ This work; ${ }^{\mathrm{b}}$ Galeron et al. (2017); ${ }^{\mathrm{c}}$ average of triplicates; ${ }^{\mathrm{d}}$ average of duplicates. 


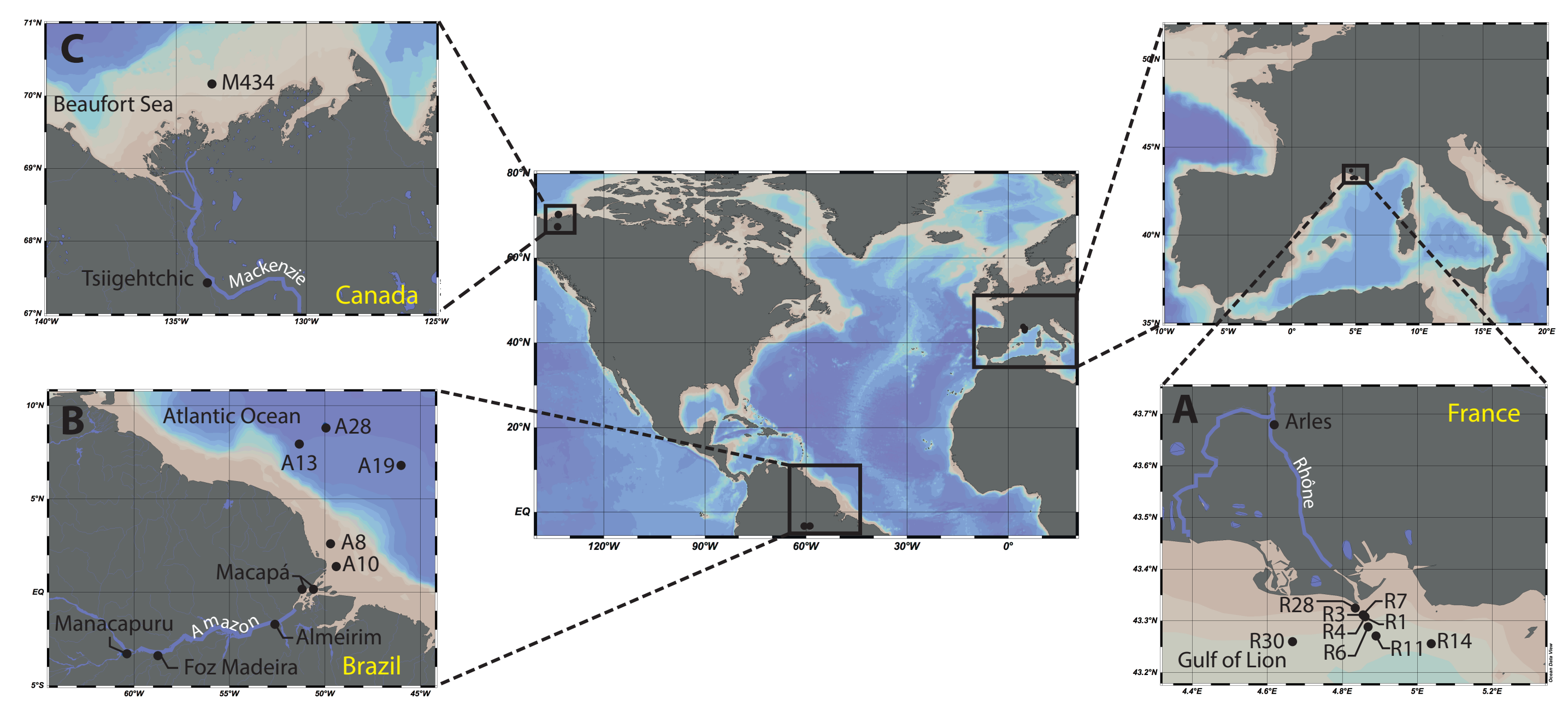


$m / z 199.1518$

$\mathrm{m} / \mathrm{z} 329.1968$

$m / z 213.1675$

$\mathrm{m} / \mathrm{z} 343.2125$

$\mathrm{m} / \mathbf{z} 225.1670$

$m / z 315.2171$

$m / z 327.1807$

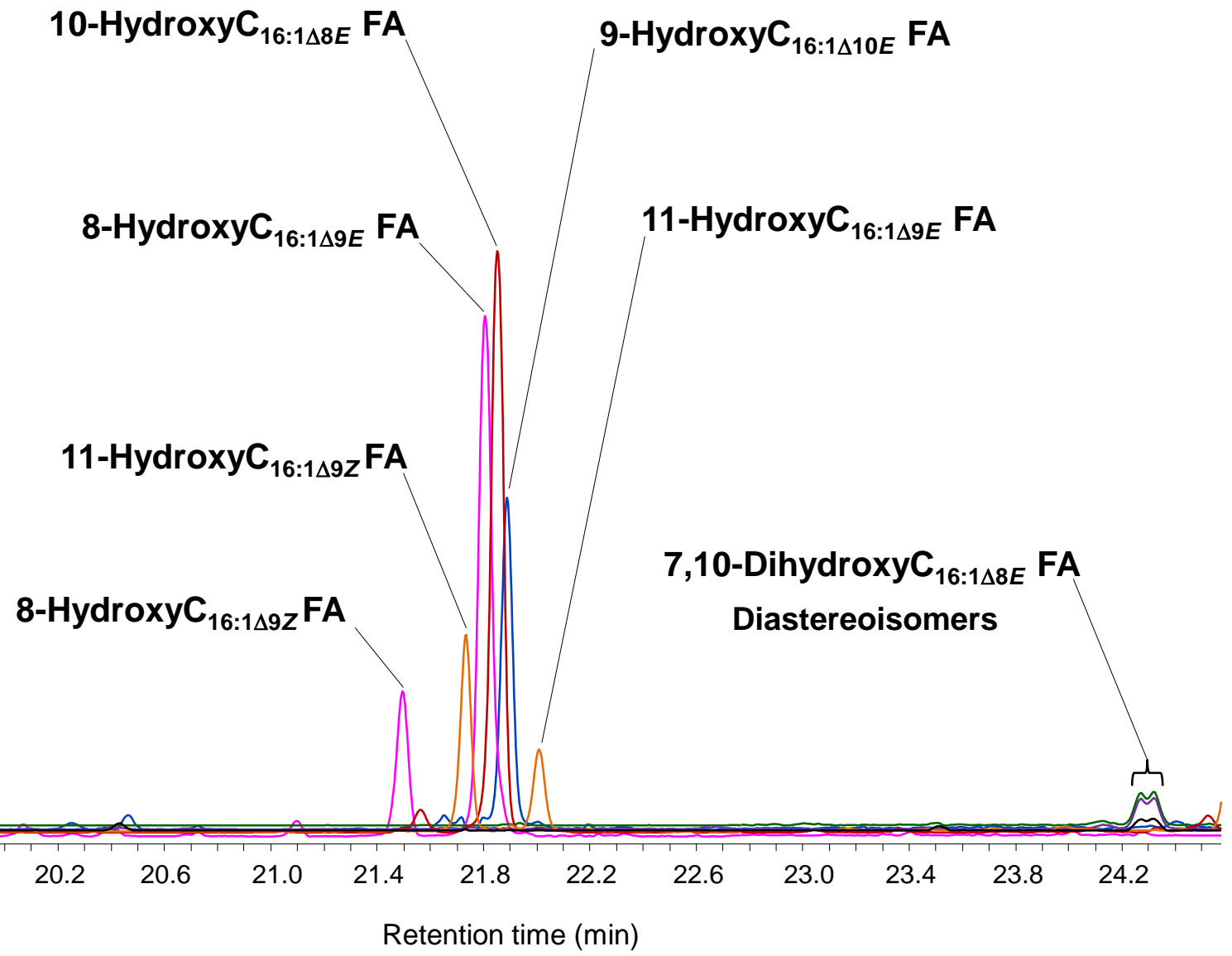




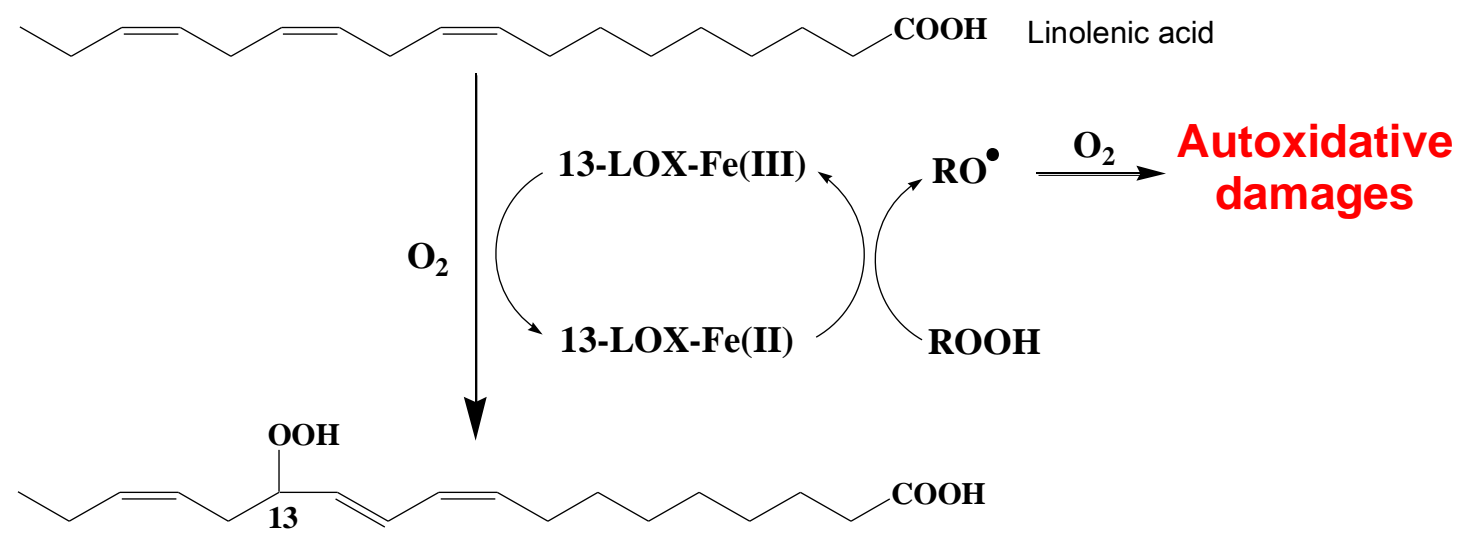

Allene oxide synthase
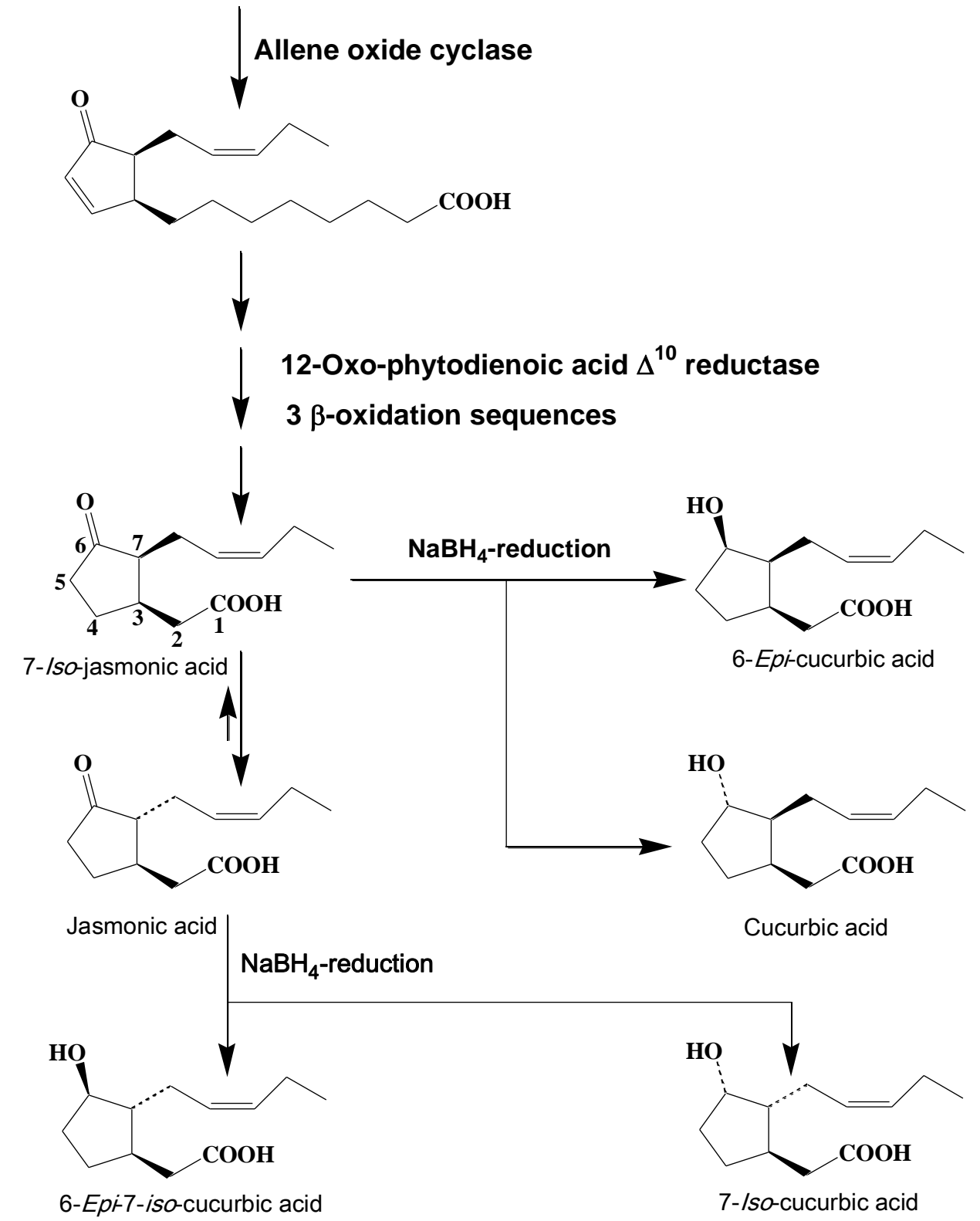
A

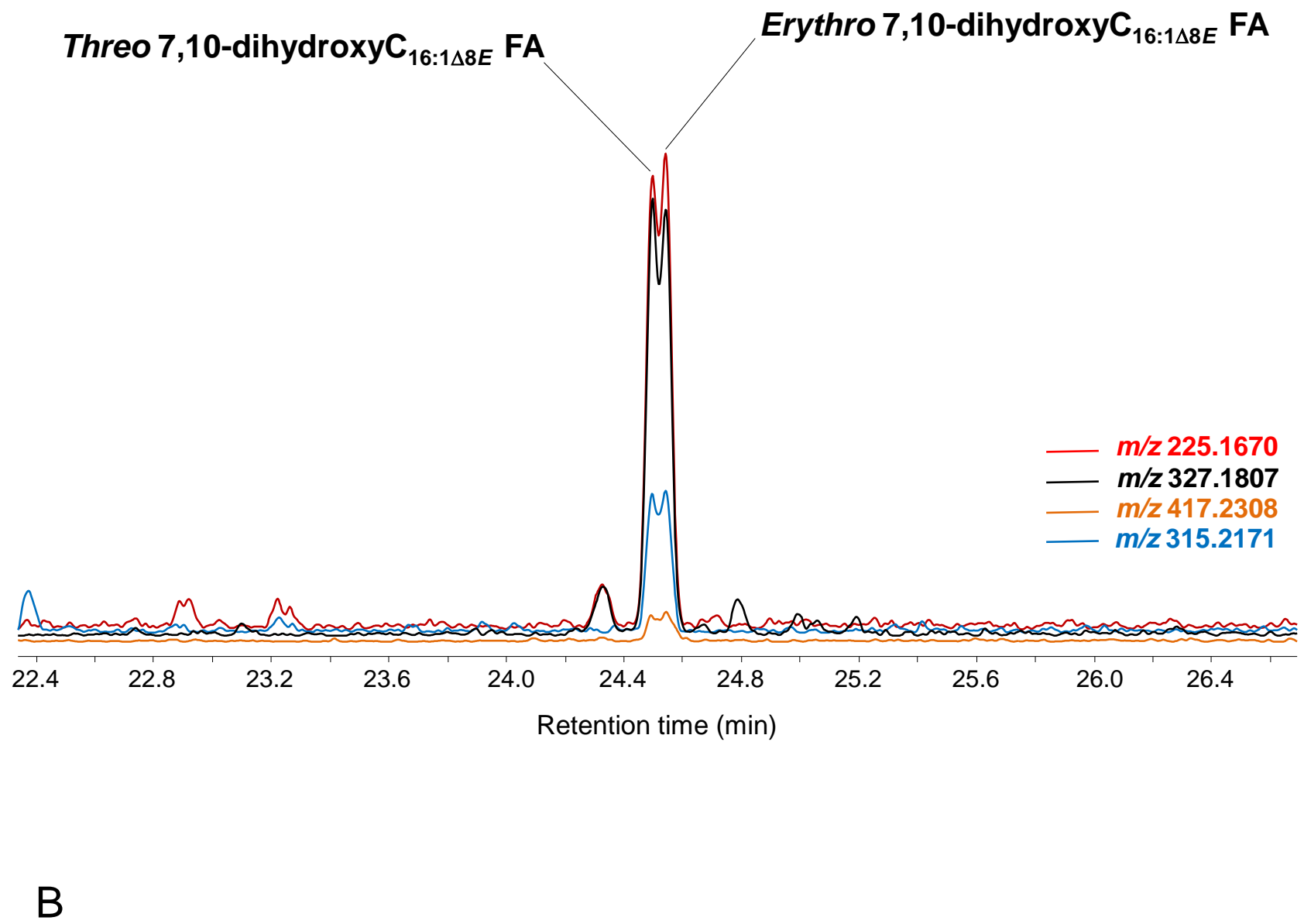

Threo 7,10-dihydroxyC $\mathrm{C}_{16: 1 \triangle 8 E} \mathrm{FA} \quad$ Erythro 7,10-dihydroxyC $\mathrm{C}_{16: 1 \triangle 8 E} \mathrm{FA}$

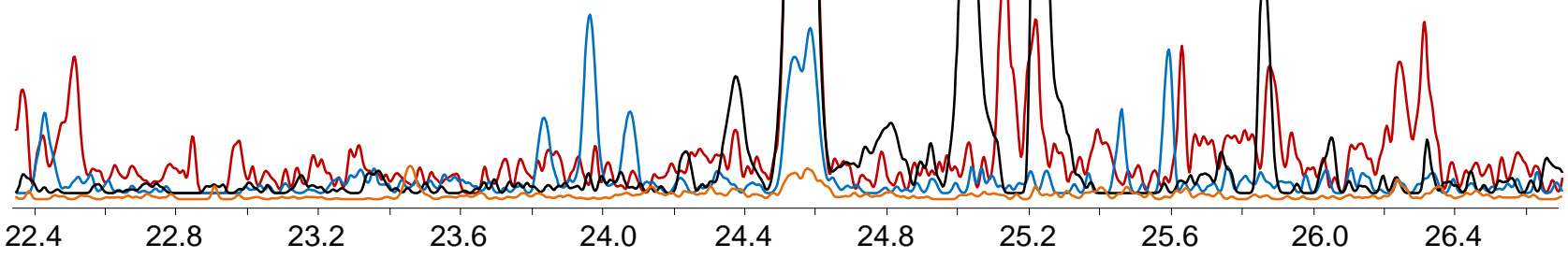

Retention time (min) 


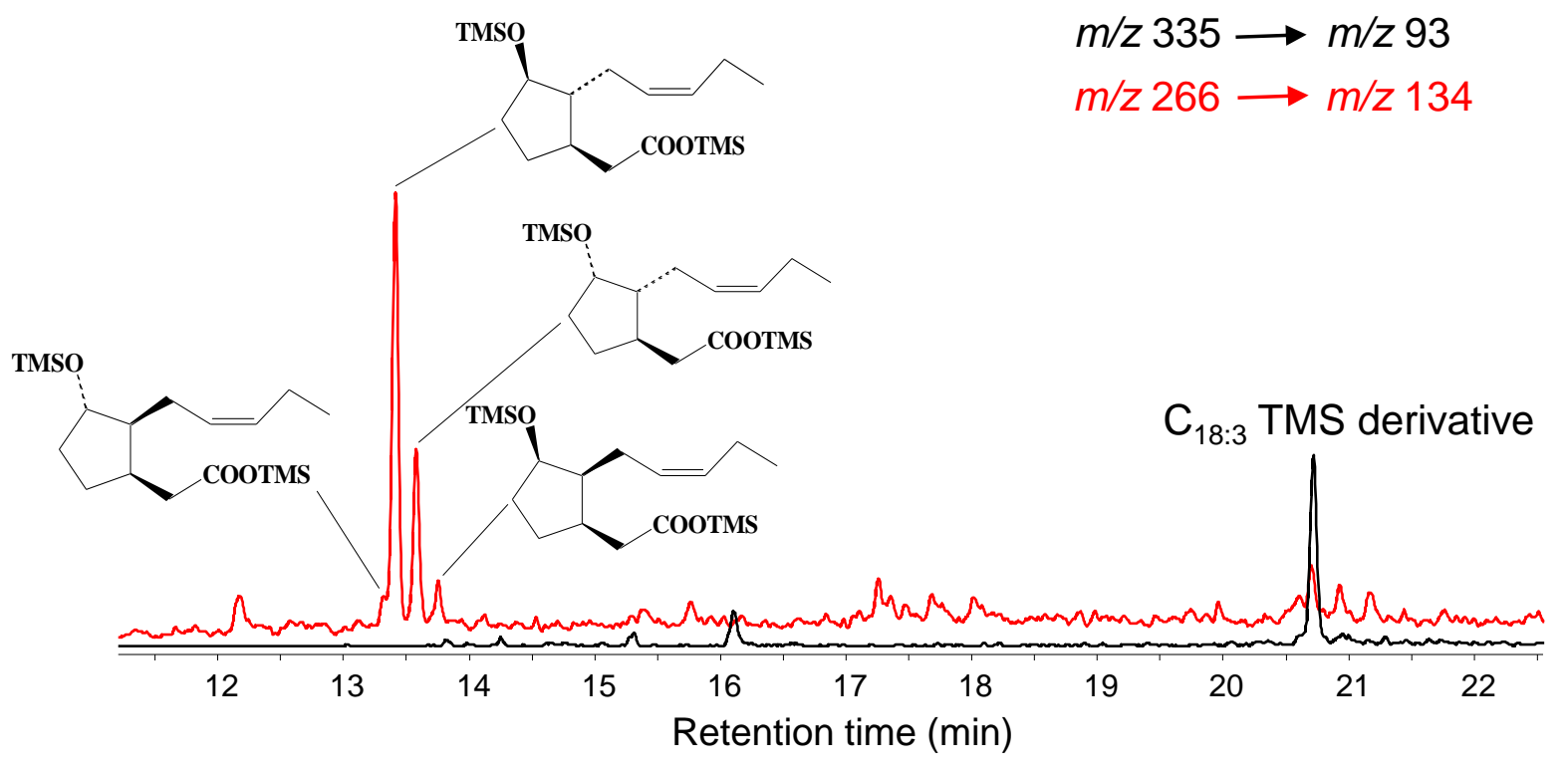

$m / z 335 \longrightarrow m / z 93$

$\mathrm{m} / \mathrm{z} 266 \longrightarrow \mathrm{m} / \mathrm{z} 134$

$\mathrm{C}_{18: 3}$ TMS derivative

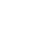




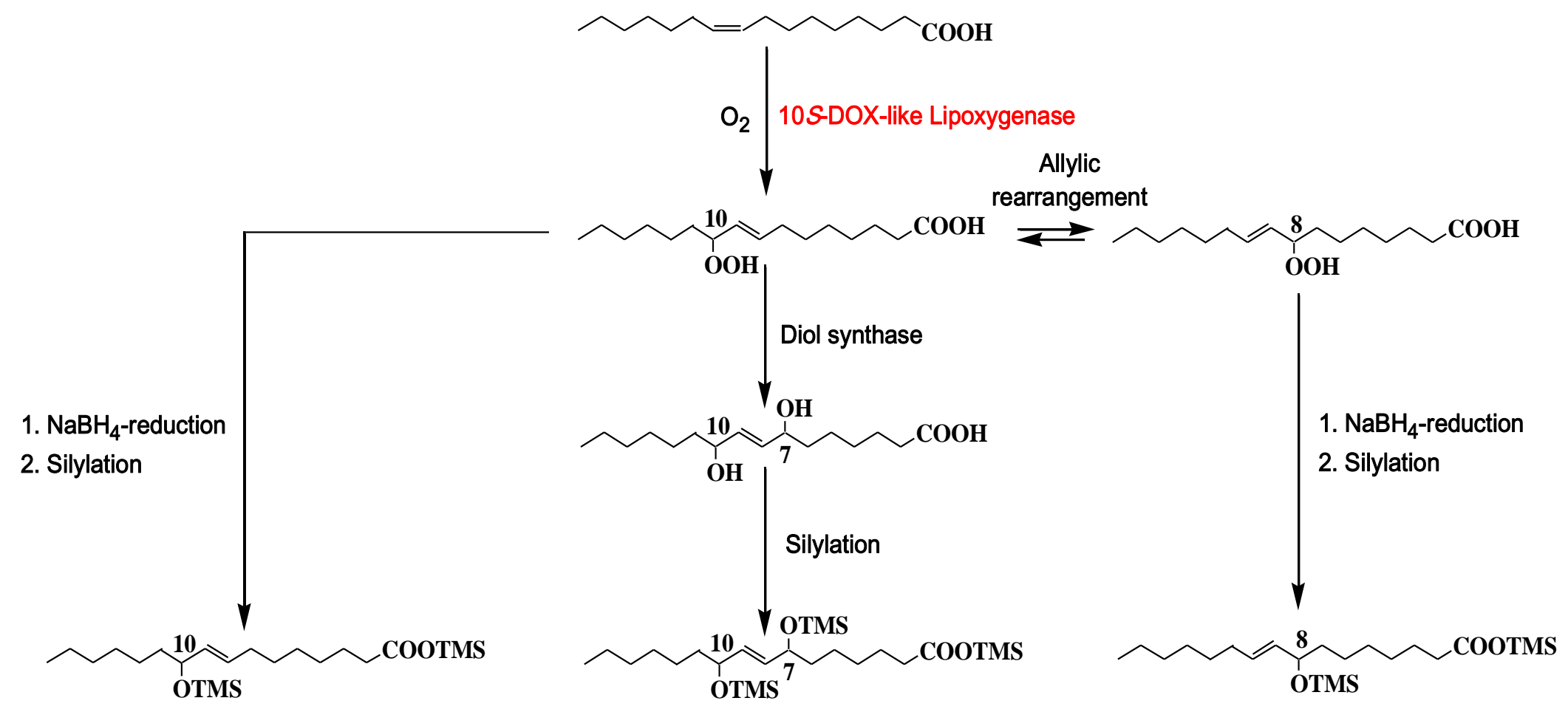




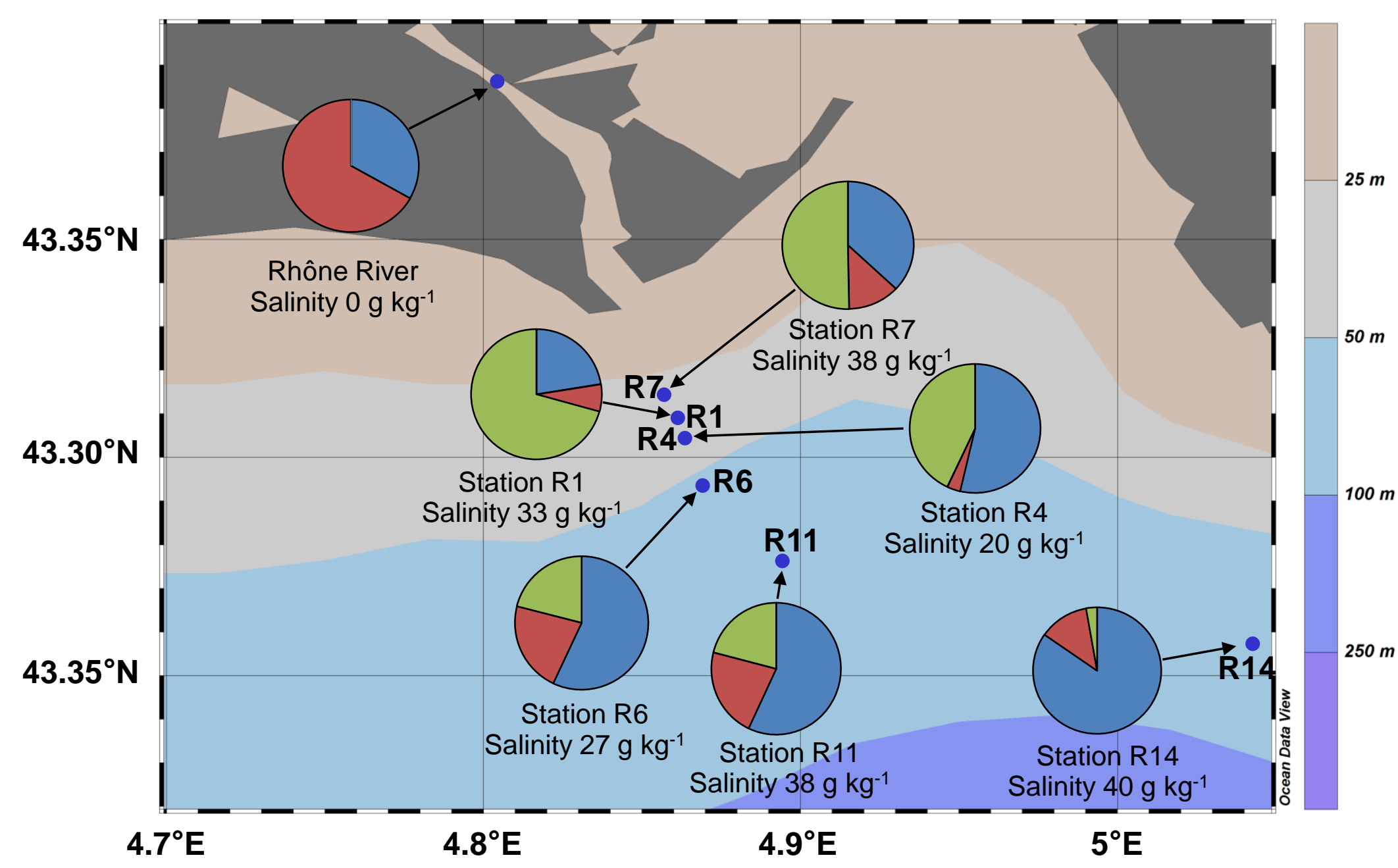

- Autoxidation \%

- Photooxidation \%

10S-DOX-like lipoxygenase oxidation \% 
River

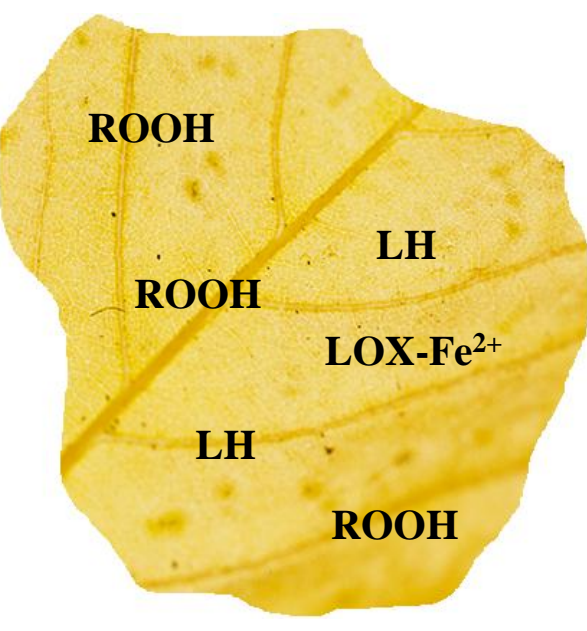

Transport by the river of higher plant debris photooxidized on land

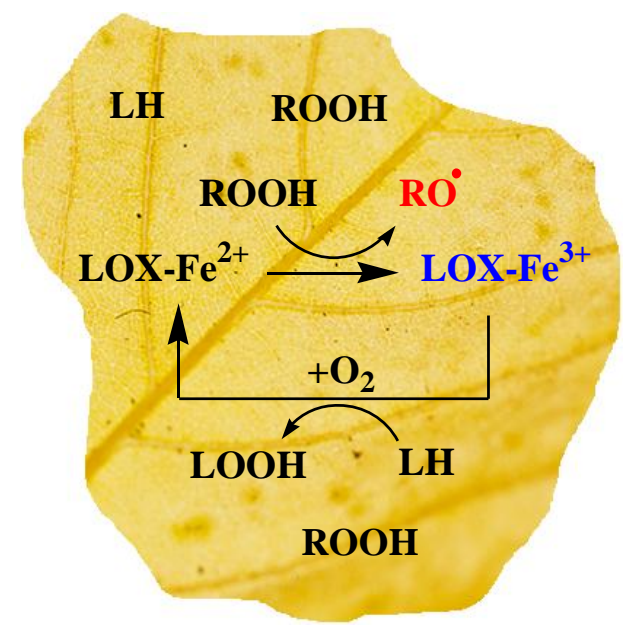

Increase of lipoxygenase activity with salinity in mixed waters Production of ROS
Sea

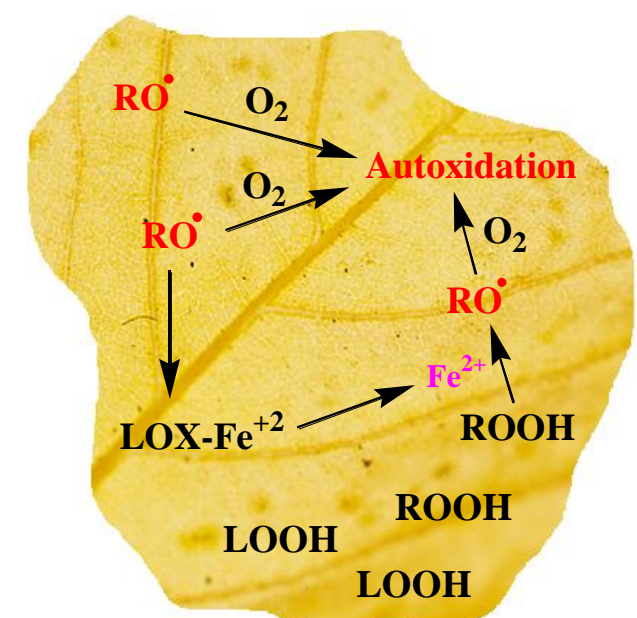

Release of ferrous ions from LOX-Fe ${ }^{2+}$ Induction of intense free radical oxidation in seawater
Salinity
ROS Reactive Oxygen Species

LH (Linoleic and linolenic acids)

ROOH (Hydroperoxides resulting from photoand autoxidation on land)

RO• (Alkoxyl radicals)

LOX-Fe ${ }^{2+}$ (Native ferrous lipoxygenase)

LOX-Fe ${ }^{3+}$ (Activated ferric lipoxygenase) 
Terrestrial higher plants degradation induced by:

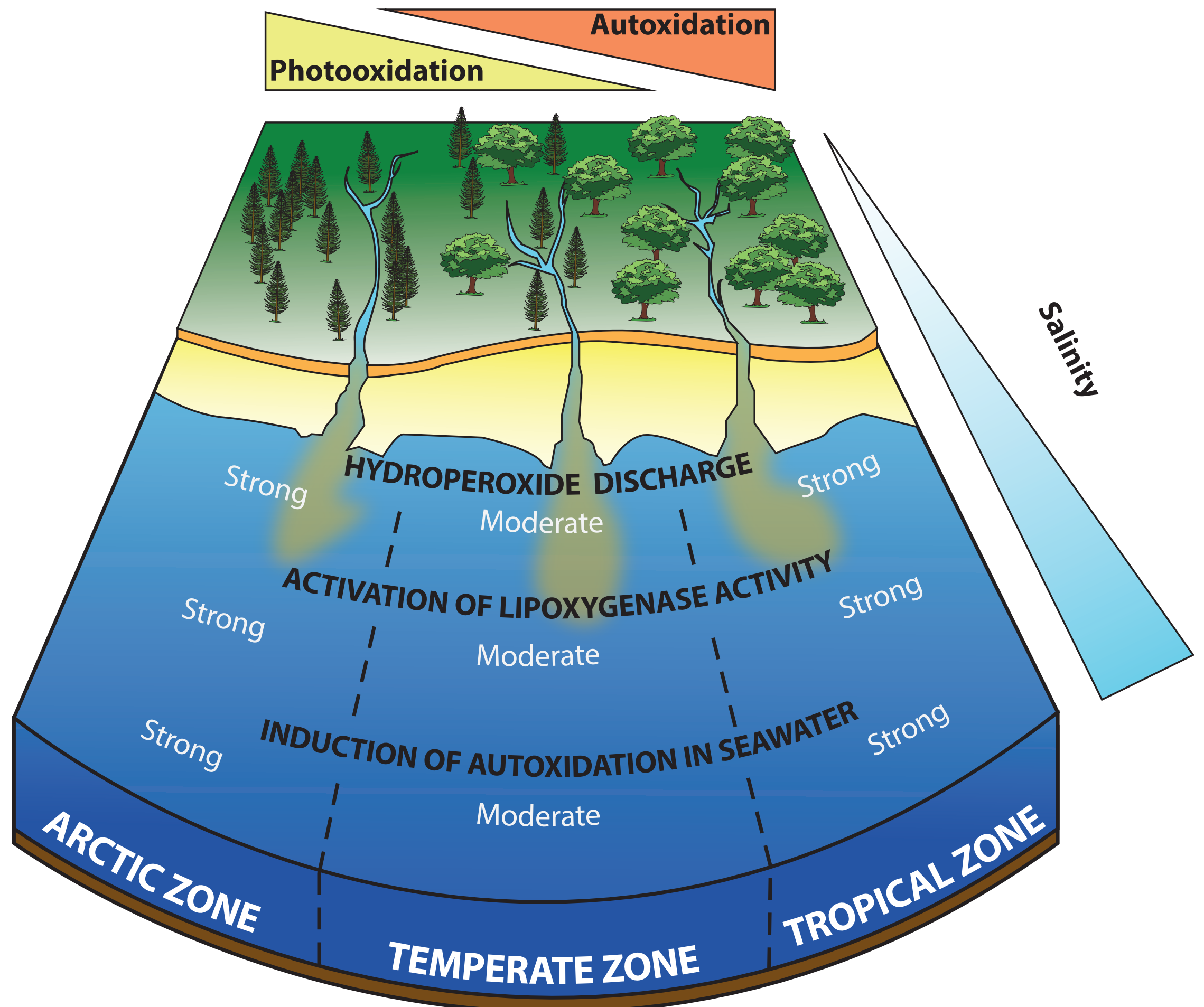

